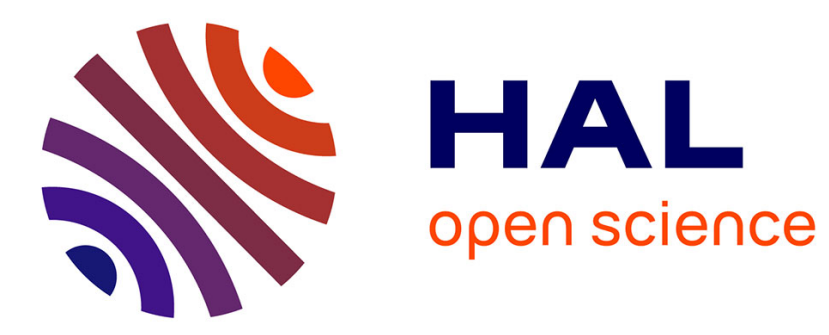

\title{
Ius gentium: The Metamorphoses of a Legal Concept (Ancient Rome to Early Modern Europe)
}

\author{
Dante Fedele
}

\section{To cite this version:}

Dante Fedele. Ius gentium: The Metamorphoses of a Legal Concept (Ancient Rome to Early Modern Europe). Edward Cavanagh. Empire and Legal Thought. Ideas and Institutions from Antiquity to Modernity, Brill | Nijhoff, pp.213-251, 2020, 9789004431249. 10.1163/9789004431249_009 . hal02648929

\section{HAL Id: hal-02648929 \\ https://hal.univ-lille.fr/hal-02648929}

Submitted on 2 Jun 2020

HAL is a multi-disciplinary open access archive for the deposit and dissemination of scientific research documents, whether they are published or not. The documents may come from teaching and research institutions in France or abroad, or from public or private research centers.
L'archive ouverte pluridisciplinaire HAL, est destinée au dépôt et à la diffusion de documents scientifiques de niveau recherche, publiés ou non, émanant des établissements d'enseignement et de recherche français ou étrangers, des laboratoires publics ou privés. 


\title{
Ius gentium
}

\section{The Metamorphoses of a Legal Concept (Ancient Rome to Early Modern Europe)}

\author{
Dante Fedele
}

Ius gentium (the law of nations) is a complex and fascinating legal concept. Its convoluted history is marked by an inner ambiguity, the product of many centuries of semantic stratification. ${ }^{1}$ In Ancient Rome - and for a long time afterwards - it was understood as a law common to all of humankind and is therefore inevitably pertinent to any discussion of law and empire. ${ }^{2}$ The problematic relationship between ius naturale (natural law) and ius gentium, moreover, was the object of in-depth analysis by medieval legal scholars and, in the early seventeenth century, ius gentium was turned into ius inter gentes (law among nations), thereby defining the domain of relations between polities. This chapter offers an attempt to explore the semantic stratification of the concept and its transformations over time, and to assess its historical role in the framing of what - since Jeremy Bentham - we have called 'international law'. This discussion begins with an outline of the history of ius gentium in Roman law. From here, it continues with a survey of the late-medieval elaboration on the concept. In the last section - following some brief references to early-modern scholarship on ius gentium, and particularly to the School of Salamanca - this chapter reveals how a thematic, rather than a conceptual, approach can be taken. The focus shifts to the contributions made (from the late sixteenth century onwards) by the literature on the ambassador to the recognition of ius gentium as a distinct legal field, distinguished from ius civile particularly by its exclusive application to external relations.

\footnotetext{
${ }^{1}$ Among recent surveys, see Heinhard Steiger, 'Völkerrecht' (1993), in Id., Von der Staatengesellschaft zur Weltrepublik? Aufsätze zur Geschichte des Völkerrechts aus vierzig Jahren (Baden-Baden: Nomos 2009) 15-65, and Andreas Thier, 'Historische Semantiken von ius gentium und "Völkerrecht", in Tilmann Altwicker (ed.), Völkerrechtsphilosophie der Frühaufklärung (Tübingen: Mohr Siebeck 2015) 29-47.

${ }^{2}$ This notion of ius gentium has recently attracted new interest, since some authors have proposed to understand it again as a 'common' rather than 'interstate' law: see for example Antônio Augusto Cançado Trindade, International Law for Humankind: Towards a New Jus Gentium, 2nd ed. (Leiden-Boston: Nijhoff 2010) and Rafael Domingo, The New Global Law (Cambridge: Cambridge University Press 2010).
} 


\section{Roman Law to Isidore of Seville}

In Ancient Rome, the oldest traces of "public international law" are found within ius fetiale rather than within ius gentium. ${ }^{3}$ In fact, ius fetiale regulated the rites used by the fetial priests to declare war or conclude a treaty with a foreign people; ius gentium, on the other hand, might originally have been a sort of interregional private law, mainly related to commercial practice, and stemming from the jurisdiction of the praetor peregrinus, i.e. the Roman magistrate created at the end of the First Punic War (242 BCE) to hear cases in which non-citizens were parties. ${ }^{4}$ The remedies introduced by the praetor peregrinus came to be seen as applying to all nations and were made available to citizens and non-citizens alike, as opposed to ius civile, which applied exclusively to Roman citizens. ${ }^{5}$ The most important innovation brought by these remedies to the legal system was the recognition of the validity of consensual agreements, which did not need any formality and were based on good faith (bona fides): they included sale, hire, mandate and partnership.

It is difficult to connect this praetorian law with subsequent jurisprudential elaboration on the concept of ius gentium. ${ }^{6}$ The idea of a universal recognition of the remedies introduced by the praetor peregrinus might have suggested that they should be based not on common practice, but on natural reason, 'which all men shared as part of their human nature'. ${ }^{7}$ In fact, although at the time it may already have been an accepted technical concept, the term ius gentium is first to be found in the work of Cicero (106 BCE- $43 \mathrm{BCE}$ ), where it is associated with natural law. The distinction, within the field of political justice, between natural justice and legal justice was an ancient one, and can be traced back to Aristotle. ${ }^{8}$ Stoic philosophers

\footnotetext{
${ }^{3}$ See Randall Lesaffer, 'Roman Law and the Intellectual History of International Law' in Anne Orford and Florian Hoffmann (eds.), The Oxford Handbook of the Theory of International Law (Oxford: Oxford University Press 2016) 41. On ius fetiale, see Alan Watson, International Law in Archaic Rome: War and Religion (BaltimoreLondon: Johns Hopkins University Press 1993) and Giovanni Turelli, 'Audi Iuppiter'. Il collegio dei feziali nell'esperienza giuridica romana (Milan: Giuffrè 2011).

${ }^{4}$ See Laurens Winkel, 'Ius gentium', in Roger S. Bagnall et al (eds.), The Encyclopedia of Ancient History (Malden: Wiley-Blackwell 2013) 3553.

${ }^{5}$ See Peter G. Stein, 'The Roman Jurists' Conception of Law', in Andrea Padovani and Peter G. Stein (eds.), The Jurists' Philosophy of Law from Rome to the Seventeenth Century (Dordrecht et al: Springer 2007) 8.

${ }^{6}$ Although numerous praetorian remedies were indeed later considered to belong to ius gentium, any connection between praetorian law as such and the emergence of the concept of ius gentium has been excluded by some scholars: see Gabrio Lombardi, Sul concetto di "ius gentium" (Milan: Giuffrè 1947) and, more recently, Roberto Fiori, 'Ius civile, Ius gentium, Ius honorarium: il problema della "recezione" dei iudicia bonae fidei'. Bullettino dell'istituto di diritto romano "Vittorio Scialoja" 101-2 (1998-1999) [published 2005], 165-97, and Emmanuelle Chevreau, 'Le ius gentium: entre usages locaux et droit romain', in Julien Dubouloz et al (eds.) L'imperium Romanum en perspective. Les savoirs d'empire dans la République romaine et leur héritage dans l'Europe médiévale et moderne (Besançon: Presses universitaires de Franche-Comté 2014) 305-20.

${ }^{7}$ Peter G. Stein, Roman Law in European History (Cambridge et al: Cambridge University Press 1999) 13.

${ }^{8}$ See Aristotle, Ethica Nicomachea, 5.7, 1134b.
} 
then elaborated a cosmopolitan notion of humanity and a notion of natural law innate in human nature. Possibly under this influence, Cicero distinguished ius gentium from ius civile, considering the latter to be subordinated to the former, which he also identified with natura. ${ }^{9}$ Nonetheless, in his writings another meaning of ius gentium can also be found, which is closer to the idea of a positive law common to all nations and grounded on custom, than to the Stoic notion of a law common to all men and grounded on reason. ${ }^{10}$ In fact, as we shall see, this ambiguity was to characterize the concept of ius gentium for a long time.

The philosophical notion of ius gentium was later developed by Gaius (d. c. 180) who, at the beginning of his Institutiones, provided a definition of ius gentium and ius civile: whereas the latter is the positive law enacted by each people for itself, the former is 'the law which natural reason has established among all human beings' and is therefore observed in equal measure by all peoples; and it is called ius gentium 'as being the law which all gentes observe'. ${ }^{11}$ In a passage of the Res cottidianae later collected in Dig. 41.1.1, ius gentium and ius civile are again distinguished: having been established among all mankind by natural reason, the former is more ancient than the latter, 'as it was promulgated at the time of the origin of the human race'. ${ }^{12}$ In so doing, Gaius emphasized the logical and chronological priority of ius gentium over ius civile, and the rational character of human nature. The question of whether this notion of ius gentium was more influenced by the Stoic idea of the logos as the basic principle of cosmic order, or by the Aristotelian two-part taxonomy of law (one law common to all mankind, another belonging to each people, both being intended as a purely

\footnotetext{
${ }^{9}$ See Cicero, De officiis, 3.17 .69 ('Itaque maiores aliud ius gentium, aliud ius civile esse voluerunt, quod civile, non idem continuo gentium, quod autem gentium, idem civile esse debet') and ibid. 3.5.23 ('natura, id est iure gentium [...]').

${ }_{10}$ See Cicero, De Haruspicum responsis, 14.32, and Id., De oratore, 1.13.56, where Cicero talks about a 'commun[e] iu[s] gentium'. In De partitione oratoria, 37.129-130, after distinguishing between natura and lex, he categorises ius gentium as part of lex (non scripta). For an analysis of the concept of ius gentium in Cicero's writings, and an appraisal of Stoic influence on his thought, see Roberto Fiori, 'La nozione di ius gentium nelle fonti di età repubblicana', in Isabella Piro (ed.), Scritti per Alessandro Corbino (Tricase: Libellula 2016) vol. 3, 109-29, with further references.

${ }^{11}$ See Gai. Inst. 1.1 (= Dig. 1.1.9): 'Quod vero naturalis ratio inter omnes homines constituit, id apud omnes [populos] peraeque custoditur vocaturque ius gentium, quasi quo iure omnes gentes utuntur' (transl. Alan Watson (ed.), The Digest of Justinian, 4 vol. (Philadelphia: University of Pennsylvania Press 1985), vol. I, 2, slightly modified. Unless otherwise specified, all translations from the Digesta are quoted from this edition). The word 'peoples (populos)', written in square brackets, is only present in the text of the Institutiones, whereas it has been expunged from the text included in the Digesta.

${ }^{12}$ See Dig. 41.1.1: 'Quarundam rerum dominium nanciscimur iure gentium, quod ratione naturali inter omnes homines peraeque servatur, quarundam iure civili, id est iure proprio civitatis nostrae. Et quia antiquius ius gentium cum ipso genere humano proditum est, opus est, ut de hoc prius referendum sit' (transl. Samuel P. Scott, The Civil Law (Cincinnati: The Central Trust Company 1932), available at https://droitromain.univ-grenoblealpes.fr, whereas Alan Watson translates 'being the product of human nature itself').
} 
human phenomenon), is still debated. ${ }^{13}$ It has also been suggested that the idea of "natural reason' might have been rooted in a common set of ancient values proper to the societies of the Mediterranean. ${ }^{14}$

In the passages above, Gaius does not define ius naturale; more broadly, in his texts a fundamental uncertainty remains as to the difference between ius naturale or naturalis ratio and ius gentium. ${ }^{15} \mathrm{~A}$ distinction between these two concepts was subsequently drawn by Ulpian (c. 170 CE-223 CE) in a passage of his own Institutiones later collected in the Digesta. This distinction, however, proves quite ambiguous. Ulpian described ius naturale as referring to 'the most elementary vital functions', namely the union of the sexes, and the procreation and education of offspring: a law which 'nature has taught to all animals'. ${ }^{16}$ Ius gentium, on the other hand, is the law observed by men: 'it is not co-extensive with natural law [...] since this latter is common to all animals whereas ius gentium is common only to human beings among themselves'. ${ }^{17}$ What is not clear in this passage is whether ius gentium too is based on nature, or on custom. The connection Ulpian makes with the definition of natural law, as well as the association of ius naturale and ius gentium established in Dig. 1.1.6 - where they are defined together as ius commune, as opposed to ius civile, which is described as ius proprium - seems to support the first solution. ${ }^{18}$ Nevertheless, the example of manumissio provided in Dig. 1.1.4 - where slavery and manumission are said to have been unknown in natural law, under which

\footnotetext{
${ }^{13}$ See on the one hand Laurens Winkel, 'The Peace Treaties of Westphalia as an instance of the reception of Roman law', in Randall Lesaffer (ed.), Peace Treaties and International Law in European History. From the Late Middle Ages to World War One (Cambridge et al: Cambridge University Press 2004) 225; and on the other Peter Haggenmacher, Grotius et la doctrine de la guerre juste (Paris: PUF 1983) 314-5, and John R. Kroger, 'The Philosophical Foundations of Roman Law: Aristotle, the Stoics, and Roman Theories of Natural Law'. Wisconsin Law Review 905 (2004), 920.

${ }^{14}$ See Chevreau, 'Le ius', 311.

${ }^{15}$ See Max Kaser, Ius gentium (Köln: Böhlau Verlag 1993) 98-104.

${ }^{16}$ Haggenmacher, Grotius, 315, who recognizes the influence of the Stoic and Pythagorean notions of natural law. However, here again the philosophical background of this definition is disputed: a Stoic influence has been also pointed to by Kroger, 'The Philosophical', 937-9, whereas according to Laurens Winkel, 'Die stoische oikeiosisLehre und Ulpians definition der gerechtigkeit'. Zeitschrift der Savigny-Stiftung für Rechtsgeschichte. Romanistische Abteilung 105 (1988), 669-79, and Id., 'Einege Bemerkungen über ius naturale und ius gentium' in Martin J. Schermaier and Zoltán Végh (eds.), Ars boni et aequi. Festschrift für Wolfgang Waldstein zum 65. Geburstag (Stuttgart: Franz Steiner 1993) 443-9, the source is Peripatetic.

${ }^{17}$ Dig. 1.1.1.3-4: 'Ius naturale est, quod natura omnia animalia docuit: nam ius istud non humani generis proprium, sed omnium animalium, quae in terra, quae in mari nascuntur, avium quoque commune est. Hinc descendit maris atque feminae coniunctio, quam nos matrimonium appellamus, hinc liberorum procreatio, hinc educatio: videmus etenim cetera quoque animalia, feras etiam istius iuris peritia censeri. Ius gentium est, quo gentes humanae utuntur. Quod a naturali recedere facile intellegere licet, quia illud omnibus animalibus, hoc solis hominibus inter se commune sit'.

${ }^{18}$ Dig. 1.1.6: 'Ius civile est, quod neque in totum a naturali vel gentium recedit nec per omnia ei servit: itaque cum aliquid addimus vel detrahimus iuri communi, ius proprium, id est civile efficimus'.
} 
all men were born free, and to have come into existence later under ius gentium - suggests that its foundations may be rooted in common custom. ${ }^{19}$

In contrast to the formal definitions formulated by Gaius and Ulpian, Hermogenian (around the turn of the third century into the fourth century) provided in his Epitome Iuris a material definition of ius gentium, consisting of a simple list of the institutions it encompasses. This definition was inserted in the Digesta immediately after Ulpian's passage on manumissiones: 'As a consequence of this ius gentium, wars were introduced, nations differentiated, kingdoms founded, properties individuated, estate boundaries settled, buildings put up, and commerce established, including contracts of buying and selling and letting and hiring (except for certain contractual elements established through ius civile) ${ }^{20}{ }^{20}$ Nothing is said here about the foundations of ius gentium: as has been remarked, the wording of the text indicates that the institutions it enumerates do not constitute ius gentium, but were introduced after it, and on its basis. ${ }^{21}$ Unlike Gaius and Ulpian, Hermogenian evokes the idea of an historical development, to the extent that ius gentium here appears to have been cut off from ius naturale and given an historical and consensual nature. It is noteworthy, moreover, that the text lists not only private law institutions, but also three institutions relating to public international law. ${ }^{22}$ This is all the more remarkable in view of the fact that, first, all the discussion about ius naturale, ius gentium and ius civile in the Digesta is presented after the partition between ius publicum and ius privatum has been introduced (Dig. 1.1.1.2), and the three legal systems are all put into the second category; and, secondly, as shown by Max Kaser, most references to ius gentium in the classical Roman legal texts deal with private law institutions. $^{23}$

That said, this connection between ius gentium and public international law institutions in Hermogenian's text was not something new. Some second-century legal sources had already understood ius gentium as related to foreign relations, although jurists were only then beginning to use the concept. The best example is probably the passage of Sextus Pomponius collected in Dig. 50.7.18, which reports opinions attributed to Publius (d. 115 BCE)

\footnotetext{
${ }^{19}$ Dig. 1.1.4: 'Manumissiones quoque iuris gentium sunt. [...] Quae res a iure gentium originem sumpsit, utpote cum iure naturali omnes liberi nascerentur nec esset nota manumissio, cum servitus esset incognita: sed posteaquam iure gentium servitus invasit, secutum est beneficium manumissionis [...]'.

${ }^{20}$ Dig. 1.1.5: 'Ex hoc iure gentium introducta bella, discretae gentes, regna condita, dominia distincta, agris termini positi, aedificia collocata, commercium, emptiones venditiones, locationes conductiones, obligationes institutae: exceptis quibusdam quae iure civili introductae sunt'.

${ }^{21}$ See Kaser, Ius gentium, 49.

${ }^{22}$ Possibly a reference to the origins of ius gentium in the jurisdiction of the praetor peregrinus, according to Winkel, 'The Peace', 226.

${ }^{23}$ See Kaser, Ius gentium, 10-4, 40-53, 75f and, for an analysis of the contracts of ius gentium, 115-65.
} 
and Quintus Mucius Scaevola (d. 82 BCE): 'If someone strikes an ambassador of the enemy, he is regarded as having acted against ius gentium, because ambassadors are regarded as inviolable'. ${ }^{24}$ Before Pomponius, the same use of the term ius gentium had been made by historians and philosophers like Sallust, Seneca, Tacit and, above all, Livy, ${ }^{25}$ who employed the term some forty times with regard to diplomatic relations between Rome and other peoples, mentioning for example the prohibition of the mistreatment of ambassadors, ${ }^{26}$ the loss of immunities for ambassadors who misbehave during their mission, ${ }^{27}$ and the lawfulness of armed defence against an armed attack not preceded by a formal declaration of war. ${ }^{28}$ Given all of the above, in his reference to institutions related to public international law, Hermogenian seems to be confirming an already established use of the term ius gentium.

Upon the convergence of these formulations of Gaius and Ulpian, another - possibly from the Institutiones of Aelius Marcianus (from the second or third century) - was added to the mix in a rather confusing passage of Justinian's Institutiones that deals with the tripartition of ius naturale, ius gentium and ius civile. ${ }^{29}$ Justinian's commission here retained only the first part of Ulpian's definition, concerning ius naturale; after a brief transitional passage, it then quoted Gaius' definition of ius civile and ius gentium, and omitted the second part of Ulpian's text. Ius naturale is thus presented as having been taught by nature to all animals, and ius gentium as having been established by naturalis ratio among all men. ${ }^{30}$ It would be natural to assume that the commission's intention was to clarify something that Ulpian had failed to make explicit, namely that ius gentium is grounded in nature, and the only thing that distinguishes it

\footnotetext{
${ }^{24}$ Dig. 50.7.18: 'Si quis legatum hostium pulsasset, contra ius gentium id commissum esse existimatur, quia sancti habentur legati. Et ideo si, cum legati apud nos essent gentis alicuius, bellum cum eis indictum sit, responsum est liberos eos manere: id enim iuri gentium convenit esse. Itaque eum, qui legatum pulsasset, Quintus Mucius dedi hostibus, quorum erant legati, solitus est respondere [...]' (transl. Watson, The Digest, vol. IV, 436, modified). According to Lombardi, Sul concetto, 117 and 363, and Fiori, 'La nozione', 128, the reference to Publius and Quintus Mucius Scaevola in this passage may suggest that the concept of ius gentium had already been used by these jurists.

${ }^{25}$ See Lombardi, Sul concetto, 92-113; Kaser, Ius gentium, ad indicem; Fiori, 'La nozione', 126-127; and Domingo, The New, 8-11.

${ }^{26}$ See Livy, $A b$ Urbe condita, 2.4 ('[legati] quamquam visi sunt commisisse ut hostium loco essent, ius tamen gentium valuit'); 4.17 ('de caede [legatorum] ruptura ius gentium'); 4.19 ('hicine est [...] ruptor foederis humani violatorque gentium iuris?'); 4.32 ('cum hostibus scelus legatorum contra ius gentium interfectorum'); 5.4 ('auctores fuere contra ius caedis impiae legatorum nostrorum'); 30.25 ('non indutiarum fides modo a Carthaginiensibus sed ius etiam gentium in legatis violatum esset').

${ }^{27}$ See ibid., 5.36 ('legati contra ius gentium arma capiunt [...]; postulatumque ut pro iure gentium violato Fabii dederentur'); 5.51 ('quam gentium ius ab legatis nostris violatum'); 6.1 ('quod legatus in Gallos - ad quod missus erat orator - contra ius gentium pugnasset').

${ }^{28}$ See ibid., 42.41 ('iure gentium ita comparatum est, ut arma armis propulsentur').

${ }^{29}$ See Haggenmacher, Grotius, 318, who draws on Moritz Voigt, Die Lehre vom ius naturale, aequum et bonum und ius gentium der Römer (Leipzig: Enrst Julius Günther 1875 [reprint Aalen: Scientia Verlag 1966]) 566f for the attribution of this definition to Marcianus, and considers this passage 'un curieux ménage à trois' .

${ }^{30}$ Inst. 1.2 pr.-1: the pr. reports Ulpian's definition of ius naturale, then $\S 1$ introduces Gaius' definition with the words 'Ius autem civile vel gentium ita dividitur'.
} 
from ius naturale is its rational foundation, which specifically distinguishes mankind from other animals. This assumption, however, is erroneous. In fact, Marcianus' text (§ 2) again distinguishes ius civile from ius gentium, as Gaius had done in $\S 1$; but instead of relating the latter to naturalis ratio, the following statement is given:

ius gentium is common to the entire human race, for gentes have established for themselves certain regulations exacted by custom and human necessity. For wars have arisen, and captivity and slavery, which are contrary to natural law, have followed as a result, as, according to ius naturale, all men were originally born free; and from ius gentium nearly all contracts, such as purchase, sale, hire, partnership, deposit, loan, and innumerable others have been derived. ${ }^{31}$

Marcianus' definition makes it clear that the source of ius gentium is not nature, but human will impelled by practical needs. This move towards positive law is emphasized by the explicit remark that ius gentium (insofar as it encompasses war, captivity and slavery) distances itself from the precepts of ius naturale. ${ }^{32}$ Incidentally, and contrary to what has just been said in the passage taken from Ulpian, ius naturale as understood by Marcianus is rooted in 'divine providence' rather than in nature, and is common only to mankind: 'natural laws [naturalia iura] that are observed without distinction by all gentes and have been established by a certain divine providence remain always fixed and unchangeable; but those which every civitas establishes for itself are often changed either by the tacit consent of the people, or by some other law subsequently enacted'.${ }^{33}$ Returning to ius gentium, Marcianus' definition indicates a set of institutions and, several decades before Hermogenian's, divides these institutions even more explicitly into two groups, those relating to a category akin to public international law, and those relating to private law.

The semantic stratification of Roman law ideas from this time defies any attempt to find a synthesis between the various definitions laid out in the legal texts. Ius civile is plainly described as a positive law established by each people and subject to change over time; ius naturale, whether grounded in nature or in divine providence, common to all animals or only

\footnotetext{
${ }^{31}$ Inst. 1.2.2: 'Ius autem gentium omni humano generi commune est. Nam usu exigente et humanis necessitatibus gentes humanae quaedam sibi constituerunt: bella etenim orta sunt et captivitates secutae et servitutes, quae sunt iuri naturali contrariae (iure enim naturali ab initio omnes homines liberi nascebantur); ex hoc iure gentium et omnes paene contractus introducti sunt, ut emptio venditio, locatio conductio, societas, depositum, mutuum, et alii innumerabiles' (transl. Scott, The Civil Law, slightly modified).

${ }^{32}$ See also Marcianus in Dig. 1.5.5.1.

${ }^{33}$ Inst. 1.2.11 (transl. Scott, The Civil Law, slightly modified).
} 
to mankind, encompasses a set of fundamental norms that are not alterable by human will; but it is hard to say where exactly ius gentium is situated between the two. In Gaius, it almost blends with ius naturale (which, however, he does not define), sharing with it both origin and scope. In Marcianus and Hermogenian, ius gentium appears much closer to ius civile than to ius naturale with regard to origin, although its scope is wider. Ulpian's definition, lastly, is simply too vague to allow any assumption to be made as to what he considers to be the natural or historical-positive origin of ius gentium. Without doubt, at least part of the trouble faced by later interpreters stemmed from the extrapolation of these definitions from their original contexts and juxtaposition in the legal compilations promulgated by Justinian. ${ }^{34}$

In sum, Roman jurists were concerned with ius gentium more in terms of general jurisprudence, or of private law, than in terms of public international law. This is particularly evident in the definitions provided by Ulpian and Gaius: the former put ius gentium into the category of 'private law' as opposed to 'public law', 35 whereas both of them maintained that ius gentium applied to men rather than to polities. ${ }^{36}$ As a result, the prime subjects of ius gentium were individuals. Historically, as we have seen, ius gentium concerned relations between Roman citizens and people without the status civitatis. After 212, however, when the constitutio antoniniana granted full civil status to all free inhabitants of the Empire, even the distinction between ius civile and ius gentium began to lose its significance, and ius gentium thus increasingly became understood as a sort of universal law. ${ }^{37}$ Nevertheless, although 'public international law' or anything of its kind was not studied as a specific domain, Livy, Seneca, Tacitus and Pomponius all worked to establish a connection between ius gentium and the institutions related to it. Pivotally, this connection was later developed by Marcianus and Hermogenian, who, in mentioning these institutions first in their definitions, seem to have given them primacy.

A later text, too, bears witness to this growing interest in interpolity relations: the Etymologiae compiled by Isidore of Seville (c. 560-636), which, more than any other, contributed to the transmission of classical learning to the Christian Middle Ages. Isidore comes to ius gentium after talking about ius naturale and ius civile, and before moving on to ius militare, ius publicum and ius Quiritum. His definition of ius naturale is modeled on

\footnotetext{
${ }^{34}$ See Aldo Schiavone, The Invention of Law in the West, transl. Jeremy Carden and Antony Shugaar (Cambridge et al.: Harvard University Press 2012).

${ }^{35}$ See Dig. 1.1.1.2.

${ }^{36}$ See Dig. 1.1.1.4 ('solis hominibus inter se commune sit') and Dig. 1.1.9 ('quod vero naturalis ratio inter omnes homines constituit'), although they also mention gentes, and Gaius mentions populi too.

${ }^{37}$ See Chevreau, 'Le ius', 314.
} 
Ulpian's, insofar as it refers to natural instinct and to institutions like the union of the sexes, and the children's inheritance and education, but he limits its scope to human nations. ${ }^{38}$ On the other hand, ius civile is 'that which each people or civitas has established particular to itself, for divine or human reason'. ${ }^{39}$ As for ius gentium, Isidore's definition, which consists of a list of institutions, is fairly close to that of Hermogenian, although the (short) etymological explanation with which he concludes seems to evoke Gaius' Institutiones:

Ius gentium concerns the occupation, building, and fortification of settlement regions, wars, captivities, enslavements, the right of return, treaties of peace, truces, the inviolability of ambassadors, the prohibition of marriages between different races. And it is called ius gentium because nearly [fere] all nations use it. ${ }^{40}$

Álvaro d'Ors and Juan de Churruca have argued that, by introducing the word fere, Isidore was omitting the barbarians (which Gaius had not mentioned, limiting his scope to the Mediterranean people in regular contact with Rome). Laurens Winkel has explained this difference by recalling the Stoic influence on Gaius' definition, in which 'the ratio was supposed to be shared with every human being, independently from legal relations with Rome' ${ }^{41}$ Whatever it be, it is important to point out that Isidore relates ius gentium almost exclusively to the field of relations between and among polities. ${ }^{42}$ Like Marcianus and Hermogenian, he seems to understand ius gentium as positive law, grounded in custom; yet, unlike them, he excludes property and contracts, and focuses on the institutions that concern relations between polities, adding to their list peace agreements, truces and the inviolability of ambassadors. Our limited knowledge of the sources used for this section of the Etymologies makes it difficult to say how original this passage was; but Isidore's emphasis on foreign

\footnotetext{
${ }^{38}$ See Isidore of Seville, Etymologies V.4.1-2: 'Ius naturale [est] commune omnium nationum [...]'.

${ }^{39}$ Ibid. V.5: 'Ius civile est quod quisque populus vel civitas sibi proprium humana divinaque causa constituit' (transl. Stephen A. Barney et al (eds.), The Etymologies of Isidore of Seville (Cambridge et al: Cambridge University Press 2006) 118A, slightly modified).

${ }^{40}$ Ibid. V.6: 'Ius gentium est sedium occupatio, aedificatio, munitio, bella, captivitates, servitutes, postliminia, foedera pacis, indutiae, legatorum non violandorum religio, conubia inter alienigenas prohibita. Et inde ius gentium, quia eo iure omnes fere gentes utuntur' (transl. Barney, The Etymologies, 118A, modified; for the first part of the definition I follow the translation of Juan de Churruca, 'La definición isidoriana de ius gentium'. Estudios de Deusto 30 (1982), 75). In Etymologies XVIII.2, while talking about war, Isidore adds that 'hoc est enim ius gentium, vim vi expellere', which seems to refer to defensive war.

${ }^{41}$ See Churruca, 'La definición', 94, and Winkel, 'The Peace', 227.

${ }^{42}$ Even concerning the prohibition of mixed marriages, Juan de Churruca holds 'lógicamente comprensibile' its inclusion amongst the institutions of ius gentium, since it derives directly from public relations between peoples (Churruca, La definición, 91).
} 
relations has been linked to Patristic thought on this domain, and especially to Augustine's teaching on just war. ${ }^{43}$

\section{The Late Middle Ages [header]}

Gratian and the Glossators [subheader]

From the eleventh century onwards, the concept of ius gentium was increasingly used in documents stemming from practice, in relation to a wide range of issues such as ambassadorial immunity, the punishment of rebels, the privileges of merchants and keeping faith, with the result that an appraisal of its exact meaning at that time is problematic ${ }^{44}$. However, during the twelfth century a theoretical discussion began, based on the texts anlysed in the previous section. Isidore's definition of ius gentium was incorporated by Gratian into the Decretum (c. 1140) and thereby became as authoritative and widespread in medieval legal scholarship as the definitions included in the Roman law compilations. The content of the first two distinctiones of the Decretum is entirely taken from chapters 2-17 of the de legibus section of the Etymologiae, to which Gratian simply added some commentaries of his own (dicta). The concept of ius naturale in particular has given rise to debate among scholars of natural law. ${ }^{45}$ This is largely because it is defined twice in the compilation and in two different ways: in the dictum introductory to the first distinctio, Gratian states that "natural law is what is contained in the Law [i.e. the law of Moses] and the Gospel' and mentions the Golden Rule of Matthew 7:12 ('Whatever you want men to do to you, do so to them'), thus equating natural law with divine law. ${ }^{46}$ Rudolf Weigand has shown that this definition occurs three other times in the

\footnotetext{
${ }^{43}$ See Salvatore Puliatti, 'Ius gentium e disciplina dei rapporti internazionali in Isidoro di Siviglia', in Gisella Bassanelli Sommariva and Simona Tarozzi (eds.), Ravenna Capitale. Uno sguardo ad Occidente. Romani e Goti - Isidoro di Siviglia (Santarcangelo di Romagna: Maggioli 2012) 33; Kaser, Ius gentium, 51; and Karl-Heinz Ziegler, 'Ius gentium als Völkerrecht in der Spätantike', in Robert Feenstra et al (eds.), Collatio iuris Romani. Études dédiées à Hans Ankum à l'occasion de son $65^{e}$ anniversaire (Amsterdam: J.C. Gieben 1995), t. II, 66575. It has also been remarked that, although he dealt with ius belli and ius pacis, Augustine did not refer to ius gentium in De civitate Dei: see Mary M. Keys, 'Religion, Empire, and Law among Nations in The City of God: From the Salamanca School to Augustine, and Back Again', in Martti Koskenniemi et al (eds.), International Law and Religion: Historical and Contemporary Perspectives (Oxford: Oxford University Press 2017) 80-1, with further references.

${ }^{44}$ See Steiger, 'Völkerrecht', 8-9 for references.

${ }^{45}$ See Michael B. Crowe, The Changing Profile of the Natural Law (The Hague: Nijhoff 1977) 74-86, and Haggenmacher, Grotius, 470-5.

${ }^{46}$ See dictum ante c. 1, d. 1: 'Ius naturae est, quod in lege et evangelio continetur, quo quisque iubetur alii facere, quod sibi vult fieri, et prohibetur alii inferre, quod sibi nolit fieri. Unde Christus in evangelio: "Omnia quecunque vultis ut faciant vobis homines, et vos eadem facite illis. Haec est enim lex et prophetae"' (transl. Gratian, The
} 
Decretum, and seems to be implicit in a fourth passage, probably reflecting a special importance attributed to it by Gratian. ${ }^{47}$ The second definition of ius naturale is found in canon 7 of the first distinctio, which, drawing on Isidore, describes it as a law common to all nations and grounded in natural instinct. On the other hand, the definitions of ius civile and ius gentium are simply taken from Isidore, without any further explanation by Gratian. ${ }^{48}$

Faced with the variety of definitions in their sources, the glossators very soon felt the need to clarify the notion of ius gentium and to situate it in relation to ius naturale. Their efforts in this direction are central to late medieval scholarly elaboration on the two notions. Initially, civil and canon lawyers, who dealt with different sources, developed somewhat different approaches. For instance, early decretists like Rufinus (whose Summa was completed around 1164) understood ius naturale as specifically pertaining to human beings and discarded Ulpian's definition, which extended its scope to all animals. ${ }^{49}$ Later on, however, the view expressed by Ulpian was adopted by theologians like Thomas Aquinas and Giles of Rome, and so the two branches of law - in this domain as in others - developed in tandem ${ }^{50}$.

Gaius' definition of ius gentium, in which the role of naturalis ratio was stressed, led jurists to acknowledge the existence of close ties between ius naturale and ius gentium, which in many cases seemed to blend into each other. ${ }^{51}$ From the beginning, the solution elaborated to avoid confusion was a typological definition of the two concepts, which listed their different meanings. Several glosses on Inst. 1.2.1 published by Weigand distinguish between a ius gentium created by nature simultaneously with mankind, and another, subsequently created by men: 'one ius gentium is born together with mankind, another after it, one is in accordance with nature, another is against it' ${ }^{52}$ On the other hand, the civilian Rogerius (d. post 1162) and the canonist Stephen of Tournai (1128-1203) were among the first jurists to set forth the various meanings of ius naturale. In his Quaestiones super Institutis, Rogerius listed three of these meanings, namely the law that nature has taught to all animals (in Ulpian's sense); the law that

Treatise on Laws (Decretum DD. 1-20) with the Ordinary Gloss, translated by Augustine Thompson O.P. and James Gordley, with an Introduction by Katherine Christensen (Washington DC: The Catholic University of America Press 1993) 3).

47 See Rudolf Weigand, Die Naturrechtslehre der Legisten und Dekretisten von Irnerius bis Accursius und von Gratian bis Johannes Teutonicus (München: Max Hueber Verlag 1967) 134-5. The references are dictum ante c. 1, d. 5 ; dictum post c. 3 , d. 6 ; dictum ante c. 1, d. 7 ; and dictum post c. 11 , d. 9.

48 See c. 8 and 9 , d. 1.

${ }^{49}$ See Ennio Cortese, La norma giuridica. Spunti teorici nel diritto comune classico, vol. I (Milan: Giuffrè 1962) 42.

50 See ibid. 72-3

${ }^{51}$ See ibid. 73 and 124.

${ }^{52}$ See Weigand, Die Naturrechtslehre, 28: 'Ius gentium aliud nascitur cum homine, aliud post hominem, aliud secundum naturam, aliud contra naturam [...]' (anonymous gloss from ms Vienna, Österreiche Nationalbibliothek, 2142, 3va). Further examples ibid. 27-9. 
is proper to mankind and corresponds to ius gentium, whose precepts include worshipping God and keeping one's promises; and finally the 'ius aequissimus' or equity, in which sense ius civile may also be considered as ius naturale (for instance, when it protects minors from injury caused by error or fraud). ${ }^{53}$ As for Stephen of Tournai, in his Summa on Gratian's Decretum, he first provided two definitions of ius naturale which are very close to the first two cited by Rogerius, then he identified it with divine law (which includes the law of Moses, the teachings of the prophets and the New Testament) and then to the law that encompasses ius humanum, ius divinum and ius naturale (common to all animals), before finally concluding with the principle, appropriate for all mankind, that good is to be done and evil is to be avoided. ${ }^{54}$ Even the notion of natura itself was dissected by Johannes Bassianus in his Lectura Institutionum, where he distinguished between nature as natural instinct common to all animals, and nature as natural reason proper to mankind, before referring to Stephen of Tournai for further discussion of the meanings of natural law. ${ }^{55}$

There were also some institutions in relation to which ius naturale and ius gentium were understood to be totally opposed to each other: slavery (servitus) and ownership (dominium) in particular. ${ }^{56}$ Among the possible solutions to this conflict, jurists developed an idea of the historical development of human juridical relations subsequent to the creation of mankind (an idea already suggested in the passages by Marcianus and Hermogenian quoted above) ${ }^{57}$ Dealing with Dig. 1.5.4.1, according to which 'slavery is an institution of ius gentium whereby, contrary to nature, a person is subjected to the dominion of another', Irnerius (d. post 1125) glossed the words contra naturam by referring to the lex posterior rule: as lex posterior, ius gentium could derogate to ius naturale while keeping the harmonious unity of the legal system as a whole. ${ }^{58}$ Concerning ownership, Laurentius Hispanus (c. 1180-1248), in his gloss apparatus on the Decretum (1210-18), made comments on the words 'through another's field [per agrum alienum]' by using the concept of ius naturale primaevum to evoke the legal system supposedly in force before the introduction of private ownership. ${ }^{59}$ This concept in particular,

\footnotetext{
53 See ibid. 39.

54 See ibid. 148.

${ }^{55}$ See ibid. 49-50, and Cortese, La norma, 53. On this debate, as well as Weigand's magisterial study, see Crowe, The Changing, 91-2 and 98-110.

56 See Cortese, La norma, 74-90.

57 The importance of temporality is suggested by Haggenmacher, Grotius, 326. See also Thier, 'Historische Semantiken', 36-7.

58 'Aliud ius alii contrarii [...] quod remanet ex priori una cum posteriori in unum quasi corpus coniungitur: hoc in corpore enim nihil reperitur contrarium', quoted by Cortese, La norma, 75, note 99.

59 '[...] De iure naturali primevo omnia sunt communia [...]', quoted by Weigand, Die Naturrechtslehre, 251.
} 
but also others used by previous jurists like Placentinus and Stephen of Tournai, ${ }^{60}$ seemed to presuppose the existence of a ius naturale secundarium generated at a certain point in history. Commentators were to take up and develop this reasoning, which laid the foundation, and provided the terminology, for the twofold analysis of both ius naturale and ius gentium carried out in the later centuries.

In a more directly political context, the idea of a historical development of ius gentium was used by Alanus Anglicus to develop an argument in favour of the independence of national kingdoms. In fact, the English canonist drew on the concept of ius gentium and its supposed historical evolution to affirm in a famous gloss that any prince who had no superior possessed as much jurisdiction in his kingdom as the emperor in the empire, 'for the division of kingdoms that has been introduced nowadays by ius gentium is approved by the pope, although the ancient ius gentium held that there should be one emperor in the world' ${ }^{61}$

However, although reference to ius gentium could be made to argue against imperial claims to universal sovereignty, and for the divisio regnorum, nothing suggests that ius gentium was interpreted by the glossators as specifically referring to relations between polities. The primary issue, in their eyes, was to resolve the ambiguities and contradictions in their sources through classifications and conceptual distinction. ${ }^{62}$ In their close reading of the legal texts, they followed the teaching of Ulpian and Gaius, and understood both ius naturale and ius gentium as universal law, or 'ius commune' ${ }^{63}$ Such an approach was very clearly expressed by Accursius in his Ordinary Gloss (1230s-1240s), where the term ius commune is explained by reference to these two concepts. ${ }^{64}$ As a matter of fact, in Italian legal scholarship the ius

\footnotetext{
${ }^{60}$ For Placentinus see ibid. 44 ('prima iura naturalia'); for Stephen of Tournai see supra, note 54 (in that passage Stephen mentions 'iu[s] [naturale] primitiv[um]').

${ }^{61}$ See his Apparatus 'Ius naturale' on the Decretum, second recension (1205), gloss to c. 6, d. 96, ad v. cursu, ed. Alfons M. Stickler, 'Alanus Anglicus als Verteidiger des monarchischen Papsttums', Salesianum 21 (1959) 363: '[...] Divisio enim regnorum iam iure gentium introductum [! A.M.S.] a papa approbatur, licet antiquo iure gentium unus imperator in orbe esse debetur', transl. Brian Tierney, The Crisis of Church and State: 1050-1300 (Toronto: University of Toronto Press 1988) 124, slightly modified. See Steiger, 'Völkerrecht', 11-2, and Thier, 'Historische Semantiken', 38 (who, regarding the transition from the universal empire to the regna divisa, emphasises that 'dabei wirkte [...] das ius gentium als normative Konstante dieses Ordnungswandels').

${ }^{62}$ On the glossators' method, see Andrea Errera, 'The Role of Logic in the Legal Science of the Glossators and Commentators', in Padovani and Stein, The Jurists' Philosophy, 79-119.

${ }^{63}$ See Dig. 1.1.1.3-4, Dig. 1.1.6, Dig. 1.1.9, and Inst. 1.2.1-2.

${ }^{64}$ See for instance Ordinary gloss to Dig. 1.1.6, ad v. iuri communi: 'Id est, iuri naturali quod semper est bonum $\&$ aequum. Vel gentium, de quo modo dixerat: quae sunt communia primum omnibus animalibus, secundum omnibus hominibus: ut s. eod. 1. j. in fin. [Dig. 1.1.1.3-4]'. Johannes Bassianus had already glossed the term iuri communi in this passage by writing 'idest naturali, vel gentium': see Cortese, La norma, 64, note 75.
} 
commune only came to be widely identified with the ius civile Romanorum (understood as the common law of the empire) in the fourteenth century. ${ }^{65}$

Thomas Aquinas and Giles of Rome [subheader]

During the thirteenth century, theologians too started pondering on ius gentium. Thomas Aquinas (1225-74) first introduced the concept in his commentary on Aristotle's Ethica Nicomachea (1271-2). While discussing the Aristotelian notion of natural justice (dikaion physicon, iustum naturale), he pointed out that 'jurists' had discriminated between ius naturale, common to all animals, and ius gentium, proper to man as a 'rational animal' and, as examples of institutions pertaining to the latter, he mentioned the principle of pacta sunt servanda and the inviolability of ambassadors. ${ }^{66}$

Aquinas put forward a more in-depth analysis in two sections of the Summa theologiae (1265/8-73), where he adopted two different, although related, perspectives. ${ }^{67}$ In the treatise on law, he considered whether ius gentium belongs to natural or human law. In describing it as human and positive law, common to all mankind, Aquinas explicitly referred to Isidore of Seville. Then, by making the claim that ius gentium, despite its character as human law, still differs from ius civile because of their different relation to natural law, Aquinas distanced himself from Isidore: while the former derives from natural law, 'as conclusions from premises', he wrote, the latter does so 'by way of particular determination', implying the existence of a looser connection between ius civile and ius naturale. This accounted for the universal validity of ius gentium, as opposed to the variability of ius civile. ${ }^{68}$

\footnotetext{
${ }^{65}$ See Ennio Cortese, 'Agli albori del concetto di diritto comune in Italia (sec. XII-XIII)', in Aquilino Iglesia Ferreirós (ed.), El dret comú i Catalunya. Actes del VIII simposi internacional, Barcelona 29-30 de maig de 1998 (Barcelona: Fundació Noguera 1999) 189.

${ }^{66}$ See Thomas Aquinas, In $V$ Ethic., lectio 12, n. 4: 'Iuristae autem illud tantum dicunt ius naturale, quod consequitur inclinationem naturae communis homini et aliis animalibus, sicut coniunctio maris et feminae, educatio natorum, et alia huiusmodi. Illud autem ius, quod consequitur propriam inclinationem naturae humanae, inquantum scilicet homo est rationale animal, vocant ius gentium, quia eo omnes gentes utuntur, sicut quod pacta sint servanda, quod legati etiam apud hostes sint tuti, et alia huiusmodi. Utrumque autem horum comprehenditur sub iusto naturali, prout hic a philosopho accipitur'. See Crowe, The Changing, 152-3.

${ }^{67}$ See Jean-Marie Aubert, Le droit romain dans l'euvre de saint Thomas (Paris: Vrin 1955) 99-105 for a discussion of this issue. See also Pia Valenzuela, 'Between Scylla and Charybdis. Aquinas's Political Thought and His Notion of Natural Law and Ius Gentium', in Koskenniemi et al (eds.), International Law, 43-61.

${ }^{68}$ See Thomas Aquinas, Summa theologiae I, II, q. 95, a. 4, co.: 'Dividitur ius positivum in ius gentium et ius civile, secundum duos modos quibus aliquid derivatur a lege naturae [...]. Nam ad ius gentium pertinent ea quae derivantur ex lege naturae sicut conclusiones ex principiis [...]. Quae vero derivantur a lege naturae per modum particularis determinationis, pertinent ad ius civile, secundum quod quaelibet civitas aliquid sibi accommodum determinat', transl. Summa theologica, literally translated by the Fathers of the English Dominican Province (New York: Benziger Brothers 1947-1948).
} 
The perspective changes in the treatise on justice and right, where Aquinas mulls over the distinction between ius gentium and ius naturale. Whereas before he saw lex naturalis as 'nothing else than the participation of a rational creature in the eternal law', ${ }^{69}$ and thus both ius gentium and ius civile derived from natural law through human intervention (by either deduction or determination), Aquinas' point of departure is now ius naturale. ${ }^{70}$ For him, ius naturale is 'that which by its very nature is adjusted to or commensurate with another person'. This commensuration may happen in two different ways: 'first, according as it is considered absolutely', that is without any need for rational mediation. In this sense, exemplified by the union of the sexes and the procreation of offspring, ius naturale is common to all animals, as stated by Ulpian. Secondly, 'a thing is naturally commensurate with another person, not according as it is considered absolutely, but according to something resultant from it', that is through the mediation of reason. In this sense, exemplified by ownership, ius naturale is proper to mankind and corresponds to ius gentium as defined by Gaius. ${ }^{71}$ Aquinas thus succeeded in combining the traditional sources fairly coherently, and one may wonder to what extent the mediation of reason required in the treatise on justice and right corresponds with the conclusions that, in the treatise on law, need to be drawn from natural law in order to ascertain its contents. ${ }^{72}$ Nevertheless, despite this great attempt at systematisation, the fundamental ambiguities inherent to ius gentium remain. ${ }^{73}$

In his treatise De regimine principum (1277-80), Giles of Rome too discussed ius gentium and its relation to ius naturale. After elaborating on ius naturale and ius civile, Giles points out that 'jurists' had also come to refer to another concept, that of ius gentium. He draws on Justinian's Institutiones to distinguish ius naturale, which is common to all animals, from ius gentium, which is part of ius naturale and specifically pertains to man. In his view, however, this notion of ius naturale is still too narrow, so he develops his analysis by introducing another

\footnotetext{
${ }^{69}$ See ibid. I, II, q. 91, a. 2, co.: 'Lex naturalis nihil aliud est quam participatio legis aeternae in rationali creatura'. ${ }^{70}$ On this difference between lex naturalis and ius naturale, see Aubert, Le droit, 104.

${ }^{71}$ See Thomas Aquinas, Summa theologiae II, II, q. 57, a. 3, co.: 'Ius sive iustum naturale est quod ex sui natura est adaequatum vel commensuratum alteri. Hoc autem potest contingere dupliciter. Uno modo, secundum absolutam sui considerationem [...]. Alio modo aliquid est naturaliter alteri commensuratum non secundum absolutam sui rationem, sed secundum aliquid quod ex ipso consequitur, puta proprietas possessionum. [...] Absolute autem apprehendere aliquid non solum convenit homini, sed etiam aliis animalibus. Et ideo ius quod dicitur naturale secundum primum modum, commune est nobis et aliis animalibus. A iure autem naturali sic dicto recedit ius gentium, ut iurisconsultus dicit, quia illud omnibus animalibus, hoc solum hominibus inter se commune est. Considerare autem aliquid comparando ad id quod ex ipso sequitur, est proprium rationis. Et ideo hoc quidem est naturale homini secundum rationem naturalem, quae hoc dictat. Et ideo dicit Gaius iurisconsultus, quod naturalis ratio inter omnes homines constituit, id apud omnes gentes custoditur, vocaturque ius gentium'.

${ }^{72}$ See Paulo Emílio Vauthier Borges de Macedo, Catholic and Reformed Traditions in International Law. A Comparison between the Suarezian and the Grotian Concepts of Ius Gentium (Cham: Springer 2017) 41.

${ }^{73}$ See Haggenmacher, Grotius, 330.
} 
category, that of ius animalium. Indeed, ius naturale, as he understands it, is a threefold concept, which can be broken down according to the kind of 'inclination' considered. It may be common only to mankind, as exemplified by the inclination to live in society, in which case it is properly called ius gentium. It may be common to all animals, as exemplified by the inclination to procreate, and in this case it is properly called ius animalium. But in its broadest sense, ius naturale is common to all things ('omnia entia') and consists of their desire to preserve their own being. ${ }^{74}$

The Commentators [subheader]

The observations of the glossators of the twelfth and early thirteenth centuries were collected, selected, and consolidated in the Magna Glossa compiled by Accursius in the 1230s and 1240s. Although numerous, they are scattered and little developed. From the mid-thirteenth century onwards, jurists, freeing themselves from the teaching methods that had been exclusively based on the direct reading of legal texts, adopted a renewed approach based on a greater use of dialectical legal reasoning (especially oppositiones and quaestiones) ${ }^{75}$ This new approach had two consequences for the study of ius gentium. First, jurists started to elaborate on the various institutions listed in the passages of Ulpian, Hermogenian, Gaius, and Marcianus, carrying out more in-depth analyses than were possible in short and fragmentary glosses. ${ }^{76}$ An early example of this is Jacques de Revigny's repetitio on lex Ex hoc iure (Dig. 1.1.5), in which private ownership, dominium utile, war, slavery, obligations and several contracts are investigated. ${ }^{77}$ Other commentaries can be found dealing with these and other institutions, like marriage, dowry, filiation and self-defense. ${ }^{78}$ The institution of government itself and its

\footnotetext{
${ }^{74}$ See Aegidius Romanus, De regimine principum libri III (Romae: apud Antonium Bladum 1556) II.III.25, 308v309r: '[...] Poterit ergo inclinatio naturalis sequi naturam hominis vel ut homo est, vel un convenit cum animalibus alijs, vel ut convenit cum omnibus entibus. Nam homo naturaliter appetit conservari in esse, quod et omnia entia alia appetunt: naturaliter appetit producere filios, educare prolem, quod et alia animalia concupiscunt: naturaliter etiam appetit vivere in societate secundum debita pacta, et conventiones, quod inter animalia est proprius solius hominis. [...] Trin ergo sunt aliquo modo de iure naturali [...]'.

${ }^{75}$ See Errera, 'The Role', 136-51, and Andrea Padovani, “"Tenebo hunc ordinem”. Metodo e struttura della lezione nei giuristi medievali (secoli XII-XIV)'. Tijdschrift voor Rechtsgeschiedenis 79 (2011), 353-89.

${ }^{76}$ It may be worth remembering that between Dig. 1.1.1.4 (containing Ulpian's definition of ius gentium) and Dig. 1.1.4 (Ulpian's passage on manumissiones), the compilers of the Digesta introduced two passages which provided other examples of institutions encompassed within ius gentium, and were also commented on in the late Middle Ages: the first by Sextus Pomponius (second century), mentioning reverence for God and the obedience owed to parent and homeland; and the second by Florentinus (second century), mentioning self-defence.

${ }^{77}$ See Kees Bezemer, 'A repetitio by Jacques de Révigny on the creations of the ius gentium'. Tijdschrift voor Rechtsgeschiedenis 49 (1981), 287-321. Revigny taught in Orléans from around 1260 to the 1280s.

${ }^{78}$ The relevant passages in the Justinian sources are Dig. 1.1.1.3-4, Dig. 1.1.2-5, and Inst. 1.2.1-2.
} 
attendant instruments were even considered in the frame of ius gentium. Noteworthy in this respect is the rising speculation, caused in part by the lex Omnes populi (Dig. 1.1.9), over the power of different peoples to legislate and thus to create their own bodies of law. Baldus de Ubaldis was in fact commenting on this lex and the 'foundations of kingdoms' mentioned in Dig. 1.1.5 when, in the second half of the fourteenth century, he legitimated the existence of autonomous city-republics and kingdoms, turning ius gentium - to quote Joseph Canning into 'the juristic expression of the this-worldly dimension of human government and society' ${ }^{79}$ The idea of an historical development of ius gentium was also taken up by several jurists in their endeavour to explain legal changes occurred over time, sometimes with regard to international law institutions. For instance, arguing against the occupation of land and the prescription of fines publici, Henricus de Segusio (Hostiensis, c. 1200-71) wrote that, although at the beginning of the world such occupations were certainly licit under ius gentium, and although they were possibly still licit with regard to the land of infidels, in his days among Christians everybody had to be satisfied with their own boundaries, since it was utterly impious and unjust that someone should occupy the territory of others ${ }^{80}$. Some decades later, discussing the law of captivity and postliminium, Bartolus de Sassoferrato (1313-57) maintained that 'under the ius gentium introduced by old usages' the rights to appropriate captured goods, or enslave prisoners, ought to apply between cities that recognised no superior (Florence and Pisa, in his example); nevertheless, he went on to say that 'in accordance with the usages of modern times, and of a custom long observed among Christians', the law of captivity and postliminium was no longer observed with regard to persons, but only with regard to goods ${ }^{81}$.

The second consequence of the new approach to the study of legal sources was a development of the conceptual analysis of ius naturale and ius gentium already outlined by the glossators. Towards the end of the thirteenth century, the French jurist Pierre de Belleperche

\footnotetext{
${ }^{79}$ See Joseph Canning, The Political Thought of Baldus de Ubaldis (Cambridge et al: Cambridge University Press 1987) 211; see ibid. 69 and 211 for a discussion of Oldradus de Ponte's and Andreas de Isernia's opinion that the de iure independence of kingdoms and cities from the Empire was based on ius gentium. On Oldradus, see also infra, note 86; moreover, on this issue see Alanus Anglicus' gloss quoted supra, note 61.

${ }^{80}$ See Henricus de Segusio, Lectura super quinque libris Decretalium (Argentini: impensis Georgij Übelin et Joannes Schottus 1512) ad c. 4, X3.20, ad v. per canones, 101rB: 'Sed certe etsi hoc in principio mundi de iure gentium licitum fuerit, et hodie forsan sit quo ad terram infidelium, super quo vide, quod no. j. de voto. quod super his [c. 8, X3.34], alias tamen hodie inter christianos unusquisque terminis suis debet esse contentus'.

${ }^{81}$ See Bartolus a Saxoferrato, In ius universum civile (Basileae: Froben 1562 [reprint Frankfurt am Main: Vico Verlag 2013]) ad Dig. 49.15.24, 984B, n. 16: 'Quandoque est contentio inter duas civitates, quae superiorem non recognoscunt, ut inter civitatem Florentiae \& civitatem Pisanam [...] certe de iure gentium antiquis moribus introducto, deberet esse ius captivitatis \& postli[minii] 1. postliminium in prin. s. e. [Dig. 49.15.19] \& hic [Dig. 49.15.24]. Sed secundum mores moderni temporis, \& consuetudinis antiquitus observatae inter Christianos, quantum ad personas hominum, non observamus iura captivitatis \& postliminij, nec venduntur, nec habentur servi captivi, sed quantum ad res, iura ista servamus. Cui consuetudini est standum 1. postliminium in prin. s. e. [Dig. 49.15.19 pr.]'.
} 
dwelt at length on these two concepts in his Lectura Institutionum. He first distinguished ius naturale primaevum, common to all animals in Ulpian's sense, from ius gentium defined as the 'ius naturale that pertains to men'. ${ }^{82}$ This was by now a common view, expressed by Revigny, or by his pupil Raoul d'Harcourt (Belleperche's teacher), in the Lectura Institutionum published under the name of Bartolus de Sassoferrato, ${ }^{83}$ and taken up by Belleperche himself in a repetitio on Dig. 46.1.1. ${ }^{84}$ It would also be adopted by Cynus de Pistoia and Albericus de Rosate in their later treatments of obligations ex iure gentium. ${ }^{85}$ Oldradus de Ponte would also do so in his famous consilium 69 concerning the question as to "whether all kings and princes must de iure be subject to the emperor' ${ }^{86}$ In the course of his discussion, Belleperche then drew another distinction between two kinds of ius gentium, which, although he did not label them as primaevum and secundarium, roughly correspond to the notions that would

${ }^{82}$ See Petrus de Bellapertica, Lectura Institutionum (Lugduni: apud haeredes Simonis Vincentii 1536 [reprint Bologna: Forni 1972]) ad Inst. 1.2 pr., 66-7, n. 4: 'Tamen distinguitur, quia quoddam est primaevum ius naturale quod omnibus animantibus competit. Quoddam est ius gentium quod hominibus tantum competit, dico ius naturale quod hominibus competit. Ius primaevum est commune sicut est illud quod competit omnibus animantibus. [...] ipsum ius quo homines utuntur magis secundum rationem rerum est. Ideo secundum propriam appropriationem vocatur ius gentium'. See also ibid. 104, n. 59-60 where Belleperche attributes this distinction to 'some jurists' (quidam), saying that 'ius naturale dupliciter intelligitur. Ius naturale primaevum dicitur quod natura omnia animalia docuit. [...] Alio modo sumitur ius naturale secundum quod est ius gentium quod $\&$ cum humano genere introductum est'.

${ }^{83}$ See Bartolus a Saxoferrato, In Institutiones et Authenticas commentaria (Basileae: Froben 1562 [reprint Frankfurt am Main: Vico Verlag 2007]) ad Inst. 1.2.2, 6A, n. 1. For discussion about the attribution of this Lectura, see Laurent Waelkens, 'La Lectura Institutionum de Raoul d'Harcourt'. Rivista internazionale di diritto comune 3 (1992), 79-91, and Kees Bezemer, What Jacques saw. Thirteenth century France through the eyes of Jacques de Revigny, professor of law at Orleans (Frankfurt am Main: Klostermann 1997) 140-1.

${ }^{84}$ See Petrus de Bellapertica, Commentaria in Digestum Novum (Francofurti ad Moenum: apud Georgium Corvinum 1571 [reprint Bologna: Forni 1968]) ad Dig. 46.1.1, 374, n. 3 and 6.

${ }^{85}$ See Cinus Pistoriensis, In Codicem et aliquot titulos primi Pandectorum Tomi [...] Commentaria (Francoforti ad Moenum: Sigismund Feirabendt 1578 [reprint Rome: Il Cigno Galileo Galilei 1998]) ad Dig. 1.1.5, 4vB-5rB, n. 9-10, who seems to draw on the passage of Belleperche cited in the previous note, and Albericus de Rosate, In primam Digesti Veteris Partem Commentaria (Venetiis: Società dell'Aquila che si rinnova 1585 [reprint Bologna: Forni 1974]) ad Dig. 1.1.5, 13vB-14rA, n. 15-17, who in turn follows Cynus' line of argument. Both of them justify the existence of obligations ex iure gentium (mentioned in Dig. 1.1.5), against the common theory that obligations are generated by either ius naturale or ius civile, by saying that 'obligatio naturalis est duplex': one that proceeds from ius naturale primaevum, the other that proceeds from ius naturale understood as ius gentium. It should be noted that the passage of Cynus which in the 1578 edition reads 'Sexto, obligatio naturalis est, quae tantum hominibus competit: \& ista secundum quosdam est duplex [...]' actually says 'Secunda obligatio naturalis est, quae tantum hominibus competit, et ista procedit de iure gentium quod dicitur naturale. Et ista secundum quosdam est duplex [...]' (see ms Vienna, Österreiche Nationalbibliothek, 2257, 2vB; the same text appears in the later Lectura super Digesto Veteri by Cynus, which Domenico Maffei discovered in 1963: see ms Vatican City, Biblioteca Apostolica Vaticana, Urb. lat. 172, 13rB, and ms Berlin, Staatsbibliothek zu Berlin Preußischer Kulturbesitz, Savigny 22, 19vA).

${ }^{86}$ See Oldradus de Ponte, Consilia seu responsa et quaestiones aureae (Venetiis: ex Officina Damiani Zenari 1585) 30vA-32rA. An edition of this text based on the Vienne 1481 edition and the ms Paris, Bibliothèque Nationale de France, Lat. 14335 appears in Gerald Montagu, 'Roman Law and the Emperor: The Rationale of "Written Reason" in Some Consilia of Oldradus da Ponte'. History of Political Thought 15 (1994), 1-56. Oldradus refers to 'ius naturale primevum', and to 'iu[s] gentium quod etiam naturale vocatur', ed. Montagu, 50 . On this consilium see also Brendan McManus, 'The Consilia and Quaestiones of Oldradus de Ponte'. Bulletin of Medieval Canon Law 23 (1999), 103-5. 
subsequently be known by these terms. In fact, he defined ius gentium as the law that was created simultaneously with mankind, and the use of which is based on natural instinct; but, he added, ius gentium is also the law that men established among themselves, driven by necessity, and that - unlike ius civile - they all observe, whether Jewish, Greek or pagan. ${ }^{87}$ This allowed him to conjoin the two definitions of ius gentium found in Justinian's Institutiones, and to connect them with the concept of ius naturale.

The distinction between two iura gentium was taken up again in the first half of the fourteenth century by Bartolus de Sassoferrato. In his comment on lex Ex hoc iure (Dig. 1.1.5), Bartolus first cited the distinction between ius naturale primaevum, common to all animals, and the ius naturale 'that may be called [ius] gentium, and proceeds from natural reason' ${ }^{88}$. Then, while dealing with the legal status of slaves, Bartolus went on to note that the concept of ius gentium 'consists of two parts, one that proceeds from natural reason, as keeping one's promises $[. .$.$] , another that proceeds from the custom of the various gentes'. If lacking legal$ status under the latter part, slaves could undertake legal obligations under the former, in this formulation. ${ }^{89}$ This was reiterated later in the comment on Dig. 12.6.64, again with regard to the legal status of slaves, where Bartolus evoked the notion of a historical development by specifying that ius gentium primaevum (as he called it here) was created along with the gentes by natural reason, whereas the other ius gentium was introduced later by the gentes themselves, and 'sometimes against [natural reason]' ${ }^{90}$

\footnotetext{
${ }^{87}$ See Bellapertica, Lectura ad Inst. 1.2 pr., 76-7, n. 17: 'Dico ipsum ius gentium una cum genere humano introductum est: cum fuit ponere homines statim fuit ponere ius gentium, quod procedit ex ratione regulata. [...]. Est ius naturale primaevum: et istud est scibile quod omnia animalia habent quodquidem ius naturale nihil statuit. Ius gentium est illud quod homines habent inter se ex instinctu naturae. Et plus quod peraeque omnes constituunt: et apud omnes servatur tam apud Hebraeos quam Graecos vel paganos'.

${ }^{88}$ See Bartolus, In ius, ad Dig. 1.1.5, 13B, n. 9: 'Possumus salvare gl. \& respondere, quod contraria loquuntur de iure naturali primevo communi omnibus animantibus; gl. intelligit de iure naturali, quod potest dici gentium, quod procedit ex ratione naturali'. The same distinction, albeit without the use of the word 'primaevum', can be found in his commentary on Dig. 1.1.9: see Bartolus, In ius, 17A, n. 2.

${ }^{89}$ See Bartolus, In ius, 13B, n. 9-10: 'Dominus meus, cuius opiniones procedunt de mente iuris, dicit sic, quod iusgentium habet duas partes, unam quae procedit ex ratione naturali, ut servare promissa, de quo in $1 . \mathrm{j}$. in prin. $\mathrm{j}$ de pact. [Dig. 2.14 .1 pr.]. Et secundum hanc partem, servus est aliquid. [...]. Est \& alia pars, quae procedit ex usu gentium, \& tunc habito respectu ad hanc partem, servus potest dici nullus, \& hoc respectu non posset obligari'. On the issue of the obligations of slaves, see Cortese, La norma, 83-6.

${ }^{90}$ See Bartolus, In ius, ad Dig. 12.6.64, 640B, n. 1-2: 'Debetis tamen scire, quod ius gentium est duplex. Quoddam est ius gentium, quod fuit eo ipso quod gentes esse coeperunt, naturali ratione inductum, absque aliqua constitutione iuris gentium, ${ }^{a} u t$ fidem seu promissa servaret libertus, $\&$ similia ${ }^{a}{ }^{a-a}$ ut fidem seu promissa servare, libertas, \& similia ed. Venetiis: L.A. Giunta 1596, 61rA]. Et isto iure gentium primaevo status servi non est annihilatus [...]. Quoddam est ius gentium, quo omnes gentes utuntur ex constituione earum, non secundum rationem naturalem, imo quandoque contra, ut bella, captivitates, servitutes, distinctiones dominiorum'. On ius gentium in Bartolus, see Yushi Sasaki, 'Ius gentium in der Lehre des Bartolus', in Johan A. Ankum et al (eds.), Satura Roberto Feenstra sexagesimum quintum annum aetatis complenti ab alumnis collegis amicis oblata (Fribourg: Éditions universitaires de Fribourg 1985) 421-36.
} 
The terminology in which this doctrine was eventually expressed appears to have been established by Baldus de Ubaldis (1327-1400), Bartolus' outstanding pupil. In a short passage of his comment on lex Manumissiones (Dig. 1.1.4), he considered the vexed question of whether the manumission of a slave was the revelation and releasing of primordial and natural freedom (which ius gentium had only obscured), or a true gift of freedom (since under ius gentium primordial and natural freedom had totally disappeared). ${ }^{91}$ Baldus argued for the latter option, maintaining that 'primum ius gentium has been completely overturned by secundum ius gentium'. ${ }^{92}$ The old opposition between ius naturale and ius gentium - which Baldus himself had previously adopted in his commentary on Cod. 6.1.1, in which he spoke of a ' $i u[s]$ natural $[e]$ primae intentionis' and a 'iu[s] natural[e] secundae intentionis, idest [...] iu $[s]$ gentium $^{93}$ - was thus moved onto different grounds, those of primum and secundum ius gentium. In the same vein, Baldus began his comment on lex Ex hoc iure (Dig. 1.1.5) by saying that 'haec lex tractat de secundis inventionibus iuris gentium', thereby putting all the institutions listed by Hermogenian in the category of secundum ius gentium. ${ }^{94}$

The way was now paved for the systematisation of the conceptual relations between ius naturale and ius gentium, and for a tentative taxonomy of the various institutions they

\footnotetext{
${ }^{91}$ See Cortese, La norma, 74-82.

${ }^{92}$ See Baldus de Ubaldis, In primam Digesti veteris partem commentaria (Venetiis: Società dell'Aquila che si rinnova 1599 [reprint Goldbach: Keip Verlag 2004]) ad Dig. 1.1.4, 10rB, n. 7: 'Sed gl. dicit, quod manumissio est vera datio novae libertatis, \& quod primum ius gentium est correctum funditus per secundum ius gentium'. As can be seen, Baldus attributed this opinion to the gloss, but in fact while glossing this passage Accursius drew first on the opposition between ius naturale and ius gentium, and then on the opposition between ius naturale and ius civile: see Ordinary gloss to Dig. 1.1.5, ad v. datio and nascerentur.

${ }^{93}$ See Baldus de Ubaldis, In Sextum Codicis librum commentaria (Venetiis: Società dell'Aquila che si rinnova 1599 [reprint Goldbach: Keip Verlag 2004]) ad Cod. 6.1.1, 2rB, n. 3: 'Dicas, quod de iure naturali primae intentionis omnes homines liberi nascebantur. Secus de iure naturali secundae intentionis, idest de iure gentium, quod incepit post bella, quae servitutes invenerunt, ut l. manumissiones, ff. de iust. \& iur. [Dig. 1.1.4], Inst. de iu. natu. gentium \& civi. § Ius autem gentium [Inst. 1.2.2]'. The first part of the Lectura super sexto libro Codicis was published by Baldus in Padua in 1379. The excerpt from the Lectura super prima parte Digesti Veteris quoted in the previous note is included in the first version of this work, which Baldus published in Perugia before 1390, when he moved to Pavia: see Vincenzo Colli, 'Le opere di Baldo. Dal codice d'autore all'edizione a stampa', in Carla Frova et al (eds.), VI Centenario della morte di Baldo degli Ubaldi, 1400-2000 (Perugia: Università degli Studi di Perugia 2005) 63 and 70.

${ }^{94}$ See Baldus, In primam, 10vB. In his comment on Cod. 5.12.30, however, instead of primum and secundum ius gentium we find different terminology: 'Ius naturale attento primaevo iure gentium' is the legal system under which all property was held in common, while private ownership was introduced by 'ius gentium posterius subsequutum' (see Baldus de Ubaldis, In Quartum \& Quintum Codicis libros commentaria (Venetiis: Società dell'Aquila che si rinnova 1599 [reprint Goldbach: Keip Verlag 2004]) 186rA, n. 15). Again, Baldus attributed this opinion to the gloss, but Accursius had here distinguished between ius naturale primaevo and ius naturale idest gentium: see the Ordinary gloss to Cod. 5.12.30, ad v. naturali iure. The date of Baldus' Lectura super quinto libro Codicis is still uncertain; but this passage belongs to a second version which the editio princeps called lectura secundum petiam novam: see Colli, 'Le opere', 73. In the late 1390s Baldus also referred dowry to 'iu[s] gentium secundae intentionis' in his comment on c. 20, $X$ 1.6: see Baldus de Ubaldis, Ad tres priores libros decretalium commentaria (Lugduni: La Compagnie des Libraires 1585 [reprint Aalen: Scientia Verlag 1970]) 64rB, n. 12.
} 
encompassed. Another step in this direction was made by Paulus de Castro, a pupil of Baldus'. Firstly, Paulus seems to have presupposed the scheme set forth by Bartolus and Baldus, based on the distinction between ius naturale primaevum and secundarium, and the identification of the latter to ius gentium primaevum. ${ }^{95}$ Secondly, Paulus emphasised the notion of historical development by clarifying that ius gentium primaevum had been created simultaneously with mankind, whereas ius gentium secundarium had been established subsequently by men themselves. ${ }^{96}$ Thirdly, he proposed a partial reordering of the natural law institutions listed by Isidore de Seville in the canon Ius naturale of the Decretum, assigning them to either ius naturale or ius gentium according to the time of their introduction (either the creation of men or later, respectively). ${ }^{97}$ Lastly, he distributed the ius gentium institutions into ius gentium primaevum and secundarium based on the same criterion. ${ }^{98}$

Despite some ambiguity, this doctrine, and the categorisation upon which it rested, succeeded in bringing some order to the various passages of the legal sources to which they referred. ${ }^{99}$ Other explanations would be proposed in the following century ${ }^{100}$, but the doctrine of the commentators reflected a general analytical framework which exercised a long-lasting influence on late-medieval legal scholarship. It went onto be taken up by Fernando Vázquez

\footnotetext{
${ }^{95}$ See Paulus Castrensis, In Primam Digesti Veteris partem Commentaria (Lugduni: excudit Ant. Blanc 1585) ad Dig. 1.1.4, 4rA, n. 6, concerning slavery, where Paulus equates ius gentium primaevum with the ius naturale that is proper to mankind: 'In text. ibi, cum iure naturali, id est gentium primaevo. Non autem intelligas de naturali prout est commune cum brutis, quia in brutis non est dare libertatem. \& sic nota hic quod ius gentium dicitur ius naturale. Loquor de primaevo iure gentium, quod fuit eo ipso quod gentes esse caeperunt: quia tunc non erat cognita servitus, sed inducta fuit iure gentium secundario [...]'. The distinction between ius naturale primaevum and secundarium however is only implicit in this passage. See also ibid. ad Dig. 1.1.1.3, 3rA, n. 9, where Paulus connects ius naturale (presumably secundarium) with ius gentium primaevum: 'Ultimo, violenta per vim repulsio. Sed contra, quia hoc videtur de iure gentium j. e. 1. ut vim [Dig. 1.1.3]. Solutio, intellige ibi de iure gentium primaevo quod fuit eo ipso quod homines esse incaeperunt ante etiam quam multiplicarentur, illud dicitur ius naturale'.

${ }^{96}$ See the excerpts quoted in the previous note.

${ }^{97}$ See Paulus Castrensis, In Primam ad Dig. 1.1.1.3, 3rA-B. Since it deals especially with the institutions listed by Isidore (who limited the scope of ius naturale to human nations), this comment seems to consider mainly ius naturale secundarium, pertaining to men.

${ }^{98}$ See ibid. ad Dig. 1.1.5, 4rB: 'In ista lege ponuntur quaedam, quae fuerunt de secunda inventione iuris gentium secundum Baldus, id est non de primo iure gentium quod fuit eo ipso quod gentes esse coeperunt'. According to Paulus, the institutions listed in Dig. 1.1.2 and Dig. 1.1.3, as well as the freedom of Dig. 1.1.4 and the natural obligations of Dig. 1.1.5, belong to ius gentium primaevum. On the other hand, the slavery and manumission of Dig. 1.1.4, and all other institutions cited in Dig. 1.1.5, belong to ius gentium secundarium (see ibid.).

${ }^{99}$ See ibid. ad Dig. 1.1.1.3, 3rA, n. 5, about common property and ius naturale: 'Item nota communis omnium possessio, ex quo nota quod ex illo iure bona erant communia. \& sic dominia non fuerant inventa illo iure, sed iure gentium quod etiam dicitur naturale non primaevum sed secundarium: quia dudum post creationem hominis, idest postquam homines inceperunt crescere \& multiplicari, ut j. 1. ex hoc iure [Dig. 1.1.5]'. Given the reference to Dig. 1.1.5, the adjectives 'primaevum' and 'secundarium' must probably be referred to ius gentium rather than ius naturale. See also Haggenmacher, Grotius, 332-3 for some remarks about Paulus' discussion of private and public war with regard to ius gentium primaevum and secundarium.

${ }^{100}$ For instance, by Ulrich Zasius: see Susan Longfield Karr, 'Redefining Ius to Restore Justice: the Centrality of Ius Gentium in Humanist Jurisprudence', in Paul J. du Plessis and John W. Cairns (eds.), Reassessing Legal Humanism and its Claims. Petere Fontes? (Edinburgh: Edinburgh University Press 2016) 108-34.
} 
de Menchaca (1512-69) in his Controverses illustres and by the young Hugo Grotius (1583$1645)$ in his De iure praedae, to offer only a few notable and subsequently influential examples. ${ }^{101}$ Nevertheless, no facet of ius gentium specifically designated the domain of relations between polities. True it was that the inclusion of certain institutions pertaining to foreign relations, starting with war, in Hermogenian's and Marcianus' definitions, permitted this kind of application, as did the occasional if unconventional references to ius gentium in arguments for or against the independence of kingdoms. ${ }^{102}$ As an idea, however, the scope was far wider than interpolity law alone.

\section{Early-Modern Times and the Literature on the Ambassador}

The debate on ius gentium and its relationship to ius naturale gained prominence during the early-modern period. Many important studies have been done on the vast literature produced by both Catholic and Protestant authors. ${ }^{103}$ Particular attention has been paid to the elaborations of the School of Salamanca, starting with the Dominican theologian Francisco de Vitoria (1483-1546), who tackled the concept of ius gentium on several occasions, and provided two different interpretations of it. In his Relectio de potestate civili (1528), he described ius gentium as a law that had 'the validity of a positive enactment' issued by the 'whole world, which is in a sense a commonwealth'. Consequently, 'no kingdom may choose to ignore this ius gentium,

\footnotetext{
${ }^{101}$ See Haggenmacher, Grotius, 343-5, 358-9 and 365-6. Ibid. 333, note 1597, Haggenmacher observed that in Denys Godefroy's edition of the Digesta, published in Amsterdam and Leyden in 1663, the indication 'Effectus juris gentium primaevi' is provided before Dig. 1.1.2, and the indication 'Effectus juris gentium secundarii' is provided before Dig. 1.1.3-5.

${ }^{102}$ See supra, notes 61 and 86.

${ }^{103}$ As well as the studies cites supra, note 1, see Haggenmacher, Grotius, 333-99 and 484-529; Merio Scattola, Das Naturrecht vor dem Naturrecht: zur Geschichte des "ius naturae" im 16. Jahrhundert (Tübingen: Max Niemeyer 1999); Benedict Kingsbury and Benjamin Straumann (eds.), The Roman Foundations of the Law of Nations: Alberico Gentili and the Justice of Empire (Oxford et al: Oxford University Press 2010); Annabel S. Brett, Changes of State. Nature and the Limits of the city in Early Modern Natural Law (Princeton and Oxford: Princeton University Press 2011) 62-89 and 196-206; Franco Todescan, 'Jus gentium medium est intra jus naturale et jus civile: la "double face" du Droit des Gens dans la scolastique espagnole du $16^{\text {ème }}$ siècle', in PierreMarie Dupuy and Vincent Chetail (eds.), The Roots of International Law. Les fondements du droit international. Liber Amicorum Peter Haggenmacher (Leiden-Boston: Martinus Nijhoff 2014) 121-80; Gaëlle Demelemestre, 'La systématisation du droit et la théorie du ius gentium comme droit du genre humain chez François Connan'. Revue historique de droit français et étranger 12 (2016), 413-38; Macedo, Catholic; Peter Haggenmacher, 'Sources in the Scholastic Legacy. Ius Naturae and Ius Gentium Revisited by Theologians', in Samantha Besson and Jean d'Aspremont (eds.), The Oxford Handbook of The Sources of International Law (Oxford et al: Oxford University Press 2017) 45-63; Annabel S. Brett, 'Sources in the Scholastic Legacy. The (Re)construction of the Ius Gentium in the Second Scholastic', ibid. 64-81; José María Beneyto and Justo Corti Varela (eds.), At the Origins of Modernity. Francisco de Vitoria and the Discovery of International Law (Cham: Springer 2017); and Francesca Iurlaro, 'Grotius, Dio Chrysostom and the "invention" of Customary ius gentium'. Grotiana 39 (2018) $1-32$.
} 
because it has the sanction of the whole world'. ${ }^{104}$ This view of ius gentium as positive law was restated some years later, in Vitoria's lectures on the Summa theologiae of Thomas Aquinas (1534-7). Commenting on the discussion in the "treatise" on justice and right, in which Aquinas had established a close link between ius gentium and ius naturale, Vitoria again emphasised the human origin of ius gentium, whose roots are found in the 'consensus of the whole world'. ${ }^{105}$ In 1539, however, the theologian took a different position, reestablishing a connection between ius gentium and ius naturale: in his Relectio de Indis, he asserted the natural character of ius gentium and, drawing on the Institutions of Justinian, he described it as 'either ius naturale or [...] derived from ius naturale'. ${ }^{106}$

The extent to which this appears to be a contradiction, and by extension, the reasoning behind such a contradiction, are questions of some interest, but they should not distract us from appreciating that Vitoria's analysis of ius gentium (like, indeed, that of the School of Salamanca more broadly) was noteworthy for defining this law and giving it a rightful place between ius naturale and ius civile. In fact the link between ius gentium and natural reason was - slowly but steadily - weakened over time, as is especially evident in the doctrine articulated by the jurist Fernando Vázquez de Menchaca and the Jesuits Louis de Molina (1535-1600) and Francisco Suárez (1548-1617). ${ }^{107}$ Suárez, in particular, actually rejected the Vitorian notion of a natural community - identified with the 'whole world' - to which states were to be subjected. Instead he described the ius gentium as positive, human law based on treaties and customary usage. Crucially, then, he went on to elaborate a new distinction within the concept of ius gentium: no longer between ius gentium primarium and secundarium, but between two kinds of human, positive ius gentium. His 'most revolutionary move' was thus to distinguish a ius inter gentes - a law between separate gentes, which could only properly be called ius gentium - from a mere ius intra gentes - that is a set of civil laws and institutions common to all, or nearly all, gentes. 'I add for further clarity', Suárez, happily for us, gestured:

\footnotetext{
${ }^{104}$ See Francisco de Vitoria, Relectio de Potestate Civili. Estudios sobre su Filosofía Política, ed. Jesús Cordero Pando (Madrid: Consejo Superior de Investigaciones Científicas 2008) $§ 21,62$ : '[...] ius gentium [...] habet vim legis. Habet enim totus orbis, qui aliquo modo est una respublica, potestatem ferendi leges aequas et convenientes omnibus, quales sunt in iure gentium. [...] Neque licet uni regno nolli teneri iure gentium: est enim latum totius orbis auctoritate', transl. Francisco de Vitoria, Political writings, ed. Anthony Pagden and Jeremy Lawrance (Cambridge et al: Cambridge University Press 1991) 40, slightly modified.

${ }^{105}$ See Francisco de Vitoria, Comentarios a la Secunda secundae de Santo Tomás, ed. Vicente Beltran de Heredía (Salamanca: Dominicos de la Provincias de Espana 1932-1952), t. III (1934), q. 57, a. 3, n. 5, 16: '[...] quando semel ex virtuali consensu totius orbis aliquid statuitur et admittitur, oportet quod ad abrogationem talis juris totus orbis conveniat, quod tamen est impossibile [...]'.

${ }^{106}$ See Francisco de Vitoria, 'De Indis', in Id., De Indis et de Iure Belli Relectiones, ed. Herbert F. Wright, (Washington DC: Carnegie Institution of Washington 1917) sect. III, 257: 'vel est ius naturale vel derivatur ex iure naturali', with quotation of Inst. 1.2.1 (transl. Ernest Nys, ibid. 151, slightly modified).

${ }^{107}$ See especially Todescan, 'Jus gentium'.
} 
that something can be said to belong to ius gentium in two ways [...]: in one way, because it is the law that all peoples and nations ought variously to keep amongst themselves; in another way, because it is the law that individual cities and kingdoms observe within themselves, but which is called ius gentium by similitude and appropriateness. The first way seems to me most properly to contain ius gentium, which is different in itself from ius civile. ${ }^{108}$

Here we find the first clear definition of ius gentium as something like international law, although of course Suárez did not elaborate a fully coherent system of such law understood as a specific legal field encompassing, to the exclusion of any other sources of law, all rules pertaining to relations among polities. Subsequently it fell to Richard Zouche (1590-1661), in his Iuris et iudicii fecialis (1650) to appropriate the expression 'ius inter gentes' to identify the whole domain of properly international legal relations, a domain of which he provided the first systematic treatment. ${ }^{109}$

However, even before Suárez (who published his De legibus ac Deo legislatore in 1612) there is evidence that ius gentium was starting to be understood as distinct from ius civile not only in scope, but also because of its particular application to external relations. This evolution occurred not as a result of conceptual analyses, but through the study of a cluster of issues that would later be recognized as proper topics of 'international law', and which had from the fourteenth century, and much more consistently since the sixteenth century - become the subject of specific legal treatises. In the absence of the clearly defined framework provided by a particular discipline - international law as such did not yet exist, of course - these issues were dealt with on the basis of the ius commune tradition, combining rules with varying degrees of specific applicability with others borrowed from other legal areas, but adapted to the purpose through extensive use of analogical reasoning. ${ }^{110}$ The most frequently addressed issues

\footnotetext{
${ }^{108}$ Francisco Suarez, Tractatus de legibus ac Deo legislatore (Coimbra: Apud Didacum Gomez de Loureyro 1612) II.19, 190A-190B, n. 8: 'Addo vero ad maiorem declarationem, duobus modis (quantum ex Isidoro, \& alijs iuribus, \& auctoribus colligo) dici aliquid de iure gentium, uno modo quia est ius, quod omnes populi, \& gentes variae inter se servare debent, alio modo quia est ius, quod singulae civitates, vel regna intra se observant, per similitudinem autem, \& convenientiam ius gentium appellatur. Prior modus videtur mihi proprissijme continere ius gentium re ipsa distinctum a iure civili', partially transl. Brett, 'Sources', 77, slightly modified; the expression 'most revolutionaty move' is also taken from Brett's chapter, 77.

${ }^{109}$ See R[ichard] Z[ouche], Iuris et iudicii fecialis, sive iuris inter gentes, et quaestionum de eorum explicatio (Oxoniae: excudebat H. Hall, impensis Tho. Robinson 1650) pars I, sectio I, 1-2, n. 1-2.

${ }^{110}$ See Alain Wijffels, 'Ius gentium in the practice of the Court of Admiralty around 1600', in Andrew D.E. Lewis and David J. Ibbetson (eds.), The Roman Law Tradition (Cambridge et al: Cambridge University Press 1994) 1289. See also Alain Wijffels, 'Early-modern scholarship on international law', in Alexander Orakhelashvili (ed.),
} 
included the law of war, the law of reprisals, prize law and the law of embassies. To conclude this overview of the history of ius gentium, I would like to focus briefly on the literature on ambassadors, and to provide an example of the contribution made by this literature to the emergence of a notion of ius gentium specific to external relations: the right to send and receive ambassadors in cases of civil strife. ${ }^{111}$

Although not strictly reserved to sovereign states, in this literature the right to send and receive ambassadors was only attributed to bodies politic which had a certain degree of autonomy. Subjects could only send diplomats with the permission of their ruler, and even then their envoys did not usually enjoy the status of fully fledged ambassadors. The civil wars that spread conflict and tension throughout Europe from the second half of the sixteenth century onwards, however, led jurists to wonder whether, in cases of internal revolt, the envoys of the different factions should be considered genuine ambassadors and entitled therefore to ambassadorial immunity. In France this question was tackled by the legal humanist Pierre Ayrault (1536-1601) in a work published in 1588 and entitled Rerum ab omni antiquitate judicatarum Pandectae. ${ }^{12}$ This was an encyclopedic legal text structured in many sections borrowed from the Digesta and the Codex, including one on legati. Ayrault distinguished between two types of internal disorders. When there is such discord in a state, he wrote, that only violence seems to be listened to, there is no doubt that, even in such situations, ambassadors are greetly needed, and should therefore be inviolable. On the other hand, when dealing with 'subjects', who cannot actually be called 'enemies' or 'faction leaders', just 'brigands' or 'rebels', sending them ambassadors is not legitimate, and their envoys do not enjoy the protection of ius gentium. ${ }^{113}$ Ayrault thus makes a distinction between mere rebellion,

Research Handbook on the Theory and History of International Law (Cheltenham-Northampton MA: Edward Elgar 2011) 23-60.

${ }^{111}$ Originating in the legal scholarship of the late Middle Ages, this literature spread across Europe from the midsixteenth century on, and played an important role in shaping the figure of the ambassador. These texts do not contain theoretical investigations of ius gentium as such, or of its relations to ius naturale or ius civile, but many passages deal with issues that - at least implicitly - suggest a certain understanding of this concept. See Stefano Andretta et al (eds.), De l'ambassadeur. Les écrits relatifs à l'ambassadeur et à l'art de négocier du Moyen Âge au début du XIX ${ }^{e}$ siècle (Rome: École française de Rome 2015), and Dante Fedele, Naissance de la diplomatie moderne (XIII ${ }^{e}-X V I I^{e}$ siècles). L'ambassadeur au croisement du droit, de l'éthique et de la politique (BadenBaden -Zürich/St Gallen: Nomos-Dike 2017). Another issue that could be mentioned with regard to this literature is its emphasis on history and writings related to diplomatic practice as sources of ius gentium, and on the resulting need for any ambassador to acquire an intimate knowledge of them: see Dante Fedele, 'Droit et histoire dans la formation diplomatique d'après les écrits sur l'ambassadeur et l'art de négocier (XVII'-début XVIII ${ }^{\mathrm{e}}$ siècle)'. Journal of the History of International Law, forthcoming.

${ }^{112}$ See Dante Fedele, 'The Renewal of Early-Modern Scholarship on the Ambassador: Pierre Ayrault on Diplomatic Immunity'. Journal of the History of International Law 18 (2016), 449-68.

${ }^{113}$ See Petrus Aerodius, Rerum ab omni antiquitate judicatarum Pandectae (Paris: apud Michaelem Sonnium 1588) liber X, tit. XV, cap. 23, 451r: 'Cum in Republica eo progressa dissensio est, ut arma emineant: quin eo etiam casu Legati sint valde necessarij, \& quin inviolabiles debeant esse, nulla profecto dubitatio est'. Among the 
understood as a purely internal matter, and actual civil strife, which he equates to discord in external relations: as long as the institutional foundations of the state and the political and ideological ties on which the unity of the population is based are not irredeemably compromised, there is no way for the rule of ius civile (which governs relations between rulers and their subjects) to be abandoned and replaced by that of ius gentium (which properly concerns the relations between independent polities). Only in this situation are the rebel factions warranted to send ambassadors who enjoy all the diplomatic privileges of ius gentium.

Before Ayrault, another legal humanist, François Hotman (1524-90), had touched on the same issue. In his Quaestionum illustrium liber, which appeared in 1573, in the aftermath of the St Bartholomew's Day massacre, Hotman dedicated a chapter to the question of whether faith should be kept with enemies. In his discussion, he first identified genuine 'enemies [hostes]' - who are actually 'aliens' - as distinct from 'defectors [defectores]', who should, in principle, be subject to 'our authority and rule', but have, in fact, removed themselves from it. Having made this distinction, however, Hotman went on to explain that there is a 'commonality of ius gentium' not only with hostes, but also with defectores, based on the idea - expressed by Paulus in Dig. 4.5.5.1 - that the act of defection makes someone an enemy. It followed that relations with such people should therefore also be governed by ius gentium. ${ }^{114}$ In 1585 , Alberico Gentili (1552-1608), dealing with the right of rebels to send ambassadors in his De legationibus, explicitly criticized this affirmation, and rebuked Hotman for 'stat[ing] that ius gentium holds for rebels. For the fact that we find [in the Digesta] the jurist Paulus asserting that rebels are enemies to the extent of losing their citizenship, is far from establishing the contention that they should be regarded as falling within the scope of ius gentium' ${ }^{115}$ It would thus seem that, according to Gentili, rebels never ceased to be subjects, and therefore only ius civile-never ius gentium - could apply to them. However, in focusing on civil strife, he found

examples provided, all taken from Antiquity, Ayrault cites the secession of the Roman plebis on the Aventine hill and the embassy of Menenius Agrippa dispatched by the Senate. Then Ayrault continues: 'At si ij sunt subditi, ut nondum vel hostes, vel Partium Duces possint appellari: sed duntaxat aut latrones aut rebelles: neque ad eos Legati mittendi sunt, neque missi ab iis, iure Gentium utuntur. Subditi (inquit Cicero ad Plancum) aut positis armis pacem petere debent: aut si pugnantes eam postulent, victoria pax, non pactione parienda est'.

${ }^{114}$ See Franciscus Hotomanus, Quaestionum illustrium liber ([n.p.]: excudebat Henr. Stephanus 1573) q. 7, 53 and 55: '[...] alii sunt vere proprieque Hostes, qui externi sunt [...]. Alii Defectores, qui cum imperio ac ditione nostra tenerentur, a nobis desciverunt, 1. 5, D. de cap. min. [Dig. 4.5.5] [...] Cum Defectoribus ergo iurisgentium communionem intercedere, vel eo patet, quod cum hostium numero sint, eodem quo illi iure habendi videntur: ex d.1. 5, D. de cap. min. [Dig. 4.5.5]'. In Dig. 4.5.5.1 the jurist Paulus said that '[...] deficere autem dicuntur, qui ab his, quorum sub imperio sunt, desistunt et in hostium numerum se conferunt [...]'.

${ }^{115}$ See Albericus Gentilis, De legationibus libri tres (London: excudebat Thomas Vautrollerius 1585) II.7, 54: 'Imperite vero Hotomanus in illustribus quaestionibus ius immo gentium cum defectoribus esse scribit. Quod namque Paulus I.C., defectores esse hostes dicere videtur, usque eo ut civitatem amittant: tantum abest, ut probet, iure gentium eos censendos', transl. Gordon J. Laing, De legationibus libri tres (New York et al: Oxford University Press 1924) 77, slightly modified. 
himself obliged to draw a 'distinction', as he said himself, between it and mere rebellion. On just this point, indeed, he wrote that 'when in the strife [dissensio] each faction lays claim by word and deed to the whole organization of the state [civitas] or to half of it, the ius legationis will certainly hold between the combatants [...]. But if there are some who lack the daring or the power to claim so much for themselves, in their case I believe that neither the ius legationis nor any other iura gentium ought to hold'. ${ }^{116}$

Gentili's view thus proves close to Ayrault's, and even quite similar to that of Hotman - although Hotman had not specified that, in order to enjoy the protection of ius gentium, defectors should have, or at least claim, the power to divide the state. Gentili's criticism of François Hotman was, in fact, rebutted by Jean Hotman (1552-1636), François's son, again based on the same distinction. In a treaty on the ambassador published in 1603, Jean maintained that when the number of rebels is so 'great' - 'as that in France lately was' - that 'the Estate be devided into two Factions, and each side falne into an open warre', for the sake of the 'common good' the laws applicable to the ambassadors of foreigners must also apply to citizens, 'whatsoever Alber[ico] Gent[ili] in his treatise de Legationibus saith thereof, contrary to the opinion of my late father in his booke of Notable questions'. ${ }^{117}$ Hugo Grotius later concurred: in his De iure belli ac pacis (1625), he first remarked that ius gentium 'pertains to those ambassadors whom rulers with sovereign powers send to one another. For in addition to these there are representatives of provinces, municipalities, and others, who are not governed

\footnotetext{
116 See Gentilis, De legationibus, II.9, 57: 'Ad ius quod spectat, distinctione quadam quaestionem ipse componerem. Quod in dissensione aut pars utraque totum ad se civitatis statum, aequamve portionem \& verbo, \& facto proponit pertinere: ac legationis utique ius inter istos siet. [...] Si vero quidam sint, qui tantum sibi nec audeant, nec possint vindicare, his neque iura legationis, neque alia iura gentium tribui oportere, decernimus', transl. Laing 82, slightly modified. A similar distinction can be found in Albericus Gentilis, De iure belli libri III (Hanoviae: excudebat Guilielmus Antonius 1598) I.4, 34 (on rebels, where he again criticizes François Hotman) and I.16, 118-127 (on civil war). Gentili's view was later taken up by Hieremias Setserus, Legatus: sive de Legatis Principum \& Rerumpublicarum Discursus politicus, respondente J-.E. a Worm (Frankfurt an der Oder: typis A. Eichorns 1600) assertiones CCIII-CCVII and CCXIII-CCXXI, unpaged. On Gentili's view about civil strife, see Raymond Kubben, “We should not stand beside..." International legal doctrine on domestic revolts and foreign intervention throughout the early stages of the Dutch Revolt', in Paul Brood and Raymond Kubben (eds.), The Act of Abjuration. Inspired and Inspirational (Nijmegen: Wolf Legal Publishers 2011) 119-153.

117 See Vill. H. [= Jean Hotman], L'ambassadeur ([n.p.]: [n.p.] 1603) chap. 3, 95-7: if the number of 'sujets rebelles \& seditieux [...] estoit grand, comme dernierement en France, \& que l'Estat se trouve divisé en deux factions \& le party formé en une guerre ouverte: puis que par le droit de guerre, mesmes entre les nations estrangeres \& barbares, les Herauts \& Ambassadeurs sont en sauveté: certes ceste loy doit valoir aussi bien pour les citoyens divisez que pour les estrangers ennemis d'un Estat. [...] Car l'asseurance qu'on donne aux personnes qu'ils deputent n'est pas en leur faveur, mais en la consideration du bien public, \& pour les ramener au devoir, afin de faire cesser le trouble de l'Estat. Quod est necesse turpe non est, la necessité n'a ny loy ny honte. Et c'est icy aussi que ceste belle \& ancienne maxime d'Estat doit avoir lieu Salus populi, suprema lex. Le salut de l'estat va dessus par toutes loix \& toutes considerations [...] quoy qu'en die Albericus Gentilis en son traitté de Legationibus, contre l'opinion de feu mon pere en ses questions illustres', transl. The Ambassador (London: Iames Shawe 1603) chap. 3, unpaged (the English version presents some differences, and is definitely abridged, compared to the French text).
} 
by ius gentium, which applies between different nations [inter gentes est diversas], but by ius civile'. ${ }^{118}$ Nonetheless, as Grotius later added:

in civil wars [bella civilia] [...] necessity sometimes opens the way for the exercise of this right, though in an irregular fashion. Such a case will arise when a people has been divided into parts so nearly equal that it is doubtful which of the two sides possesses sovereignty [...]. Under such circumstances a single people is considered for the time being as two peoples [duae gentes]. ${ }^{119}$

This line of thought may, in fact, be traceable through modern legal scholarship until at least the mid-eighteenth century, when Emer de Vattel (1714-67) wrote that 'civil war breaks the bonds of society and of government [...]; it gives rise, within the nation, to two independent parties, who regard each other as enemies and acknowledge no common judge'; as a consequence, 'of necessity [...] these two parties must be regarded as forming thenceforth, for a time at least, two separate bodies, two distinct peoples', since, 'although one of the two parties may have been wrong in breaking up the unity of the state and in resisting the lawful authority, still they are none the less divided in fact'. ${ }^{120}$

The idea underlying all of this reasoning is that ius gentium (and ius legationis, which is part of it) differs from ius civile, not simply because it applies to a larger domain - and can be considered a kind of universal, rather than territorial, law - but because it reveals itself to encompass the relations that separate gentes establish between themselves. Thus we see that, although no explicit conceptual elaboration of the topic is identifiable by the early modern period, the literature on the ambassador shows ius gentium inching its way towards a more

\footnotetext{
118 See Hugo Grotius, De iure belli ac pacis libri tres, ed. Bernardina J.A. de Kanter-van Hettinga Tromp, additional notes by Robert Feenstra and Caroline E. Persenaire (Aalen: Scientia Verlag 1993) II.18.2.1, 436, transl. Francis W. Kelsey, De jure belli ac pacis libri tres (Oxford-London: Clarendon Press-Humphrey Milford 1925) 439, modified. Grotius' notion of sovereignty, however, was not comparable to Bodin's: see Haggenmacher, Grotius, 537-47.

119 See Grotius, De iure belli ac pacis, II.18.2.3, 437: 'In bellis vero civilibus necessitas interdum locum huic iuri facit, extra regulam, puta cum ita divisus est populus in partes quasi aequales, ut dubium sit ab utra parte stet ius imperii: aut cum iure admodum controverso de regni successione duo decertant. Nam hoc eventu gens una pro tempore quasi duae gentes habetur', transl. Kelsey, 439-40. On this passage, and for some medieval antecedents of Grotius' conceptualisation of the two belligerent parties in a civil war as two distinct gentes, see Dante Fedele, 'Grotius and Late Medieval Ius Commune on Rebellion and Civil Strife'. Grotiana, forthcoming.

${ }^{120}$ See [Emer] de Vattel, Le droit des gens (London [recte Neuchâtel]: [Abraham Droz] 1758), t. III, III.18.293, 299: 'La guerre civile rompt les liens de la société \& du gouvernement, ou elle en suspend au moins la force \& l'effet; elle donne naissance dans la nation à deux partis indépendans, qui se regardent comme ennemis, \& ne reconnoissent aucun juge commun. Il faut donc de nécessité que ces deux partis soient considérés comme formant désormais, au moins pour un tems, deux corps séparés, deux peuples différens. Que l'un des deux ait eu tort de rompre l'unité de l'état, de résister à l'autorité légitime, ils n'en sont pas moins divisés de fait', transl. Charles G. Fenwick, Le droit des gens (Washington DC: Carnegie Institution of Washington 1916) 338, modified.
} 
specific meaning than it ever had in Antiquity and the Middle Ages ${ }^{121}$. It is probable that further analysis - extended, too, to other examples - would enable us to ascertain the extent to which the thematic approach adopted in the literature on ambassadors, the law of war, prize law and other related topics contributed to this evolution, and led jurists to arrive at an understanding of ius gentium as the legal area specifically regulating external relations. Such an analysis would undoubtedly add another remarkable piece to the history of the metamorphoses of ius gentium from universal law to ius inter gentes.

\section{BIBLIOGRAPHY}

Aegidius Romanus (1556). De regimine principum libri III. Romae: apud Antonium Bladum. Aerodius, P. (1588). Rerum ab omni antiquitate judicatarum Pandectae. Parisiis: apud Michaelem Sonnium.

Albericus de Rosate (1585). In primam Digesti Veteris Partem Commentaria. Venetiis: Società dell'Aquila che si rinnova [reprint 1974 Bologna: Forni].

Andretta S. et al, eds. (2015). De l'ambassadeur. Les écrits relatifs à l'ambassadeur et à l'art de négocier du Moyen Âge au début du XIXe siècle. Rome: École française de Rome.

Aubert, J.-M. (1955). Le droit romain dans l'œuvre de saint Thomas. Paris: Vrin.

Baldus de Ubaldis (1585). Ad tres priores libros decretalium commentaria. Lugduni: La Compagnie des Libraires [reprint 1970 Aalen: Scientia Verlag].

Baldus de Ubaldis (1599). In primam Digesti veteris partem commentaria. Venetiis: Società dell'Aquila che si rinnova [reprint 2004 Goldbach: Keip Verlag].

Baldus de Ubaldis (1599). In Quartum \& Quintum Codicis libros commentaria. Venetiis: Società dell'Aquila che si rinnova [reprint 2004 Goldbach: Keip Verlag].

Baldus de Ubaldis (1599). In Sextum Codicis librum commentaria. Venetiis: Società dell'Aquila che si rinnova [reprint 2004 Goldbach: Keip Verlag].

Barney, S.A. et al, eds. (2006). The Etymologies of Isidore of Seville. Cambridge et al: Cambridge University Press.

Bartolus a Saxoferrato (1562). In Institutiones et Authenticas commentaria. Basileae: Froben [reprint 2007 Frankfurt am Main: Vico Verlag].

\footnotetext{
121 This is not to deny that ius gentium continued to be used in (especially German) early-modern scholarship as a very broad notion: suffice here to cite the works of Samuel Pufendorf (the holder of the first chair in jus naturae et gentium, established at Heidelberg in 1661), De jure naturae et gentium libri octo (1672), and of Johann Gottlieb Heineccius, Elementa iuris naturae et gentium (1738), which are certainly not focused on external relations, but encompass the foundations and limits of secular power.
} 
Bartolus a Saxoferrato (1562). In ius universum civil. Basileae: Froben [reprint 2013 Frankfurt am Main: Vico Verlag 2013].

Bartolus a Saxoferrato (1596). In Secundam Digesti Veteris Partem. Venetiis: L.A. Giunta.

Bellapertica, P. de (1536). Lectura Institutionum. Lugduni: apud haeredes Simonis Vincentii [reprint 1972 Bologna: Forni].

Bellapertica, P. de (1571). Commentaria in Digestum Novum. Francofurti ad Moenum: apud Georgium Corvinum [reprint 1968 Bologna: Forni 1968].

Beneyto, J.M., and Varela, J.C., eds. (2017). At the Origins of Modernity. Francisco de Vitoria and the Discovery of International Law. Cham: Springer.

Besson, S., and d'Aspremont, J., eds. (2017). The Oxford Handbook of The Sources of International Law. Oxford: Oxford University Press.

Bezemer, C.H. (1981). A repetitio by Jacques de Révigny on the creations of the ius gentium. Tijdschrift voor Rechtsgeschiedenis 49, pp. 287-321.

Bezemer, K. (1997). What Jacques saw. Thirteenth century France through the eyes of Jacques de Revigny, professor of law at Orleans. Frankfurt am Main: Klostermann.

Brett, A.S. (2011). Changes of State. Nature and the Limits of the city in Early Modern Natural Law. Princeton: Princeton University Press.

Brett, A.S. (2017). Sources in the Scholastic Legacy. The (Re)construction of the Ius Gentium in the Second Scholastic. In: S. Besson and J. d'Aspremont, eds., The Oxford Handbook of The Sources of International Law. Oxford: Oxford University Press, pp. 64-81.

Cançado Trindade, A.A. (2010). International Law for Humankind: Towards a New Jus Gentium, $2^{\text {nd }}$ ed. Leiden-Boston: Nijhoff.

Canning, J. (1987). The Political Thought of Baldus de Ubaldis. Cambridge: Cambridge University Press.

Chevreau, E. (2014). Le ius gentium: entre usages locaux et droit romain. In: J. Dubouloz et al, eds., L'imperium Romanum en perspective. Les savoirs d'empire dans la République romaine et leur héritage dans l'Europe médiévale et moderne, Besançon: Presses universitaires de Franche-Comté, pp. 305-20.

Churruca, J. de (1982). La definición isidoriana de ius gentium. Estudios de Deusto 30, pp. 7195.

Cinus Pistoriensis (1578). In Codicem et aliquot titulos primi Pandectorum Tomi [...] Commentaria. Francoforti ad Moenum: Sigismund Feirabendt [reprint 1998 Rome: Il Cigno Galileo Galilei 1998].

Cinus Pistoriensis. In Codicem commentaria. Ms Vienna, Österreiche Nationalbibliothek, 2257.

Cinus Pistoriensis. Lectura super Digesto Veteri. Ms Vatican City, Biblioteca Apostolica Vaticana, Urb. lat. 172. 
Cinus Pistoriensis. Lectura super Digesto Veteri. Ms Berlin, Staatsbibliothek zu Berlin Preußischer Kulturbesitz, Savigny 22.

Colli, V. (2005). Le opere di Baldo. Dal codice d'autore all'edizione a stampa. In: C. Frova et al, eds., VI Centenario della morte di Baldo degli Ubaldi, 1400-2000, Perugia: Università degli Studi di Perugia, pp. 25-85.

Cortese, E. (1962). La norma giuridica. Spunti teorici nel diritto comune classico, Volume 2. Milan: Giuffrè.

Cortese, E. (1999). Agli albori del concetto di diritto comune in Italia (sec. XII-XIII). In: A.I. Ferreirós, ed., El dret comú i Catalunya. Actes del VIII simposi internacional, Barcelona 2930 de maig de 1998, Barcelona: Fundació Noguera 1999, pp. 173-95.

Crowe, M.B. (1977). The Changing Profile of the Natural Law. The Hague: Nijhoff.

Demelemestre, G. (2016). La systématisation du droit et la théorie du ius gentium comme droit du genre humain chez François Connan. Revue historique de droit français et étranger 12, pp. 413-38.

Domingo, R. (2010). The New Global Law. Cambridge et al.: Cambridge University Press.

Errera, A. (2007). The Role of Logic in the Legal Science of the Glossators and Commentators. In A. Padovani and P. Stein, eds., The Jurists' Philosophy of Law from Rome to the Seventeenth Century, Dordrecht: Springer, pp. 79-156.

Fedele, D. (2016). The Renewal of Early-Modern Scholarship on the Ambassador: Pierre Ayrault on Diplomatic Immunity. Journal of the History of International Law 18, pp. 449-68.

Fedele, D. (2017). Naissance de la diplomatie moderne (XIII'-XVII siècles). L'ambassadeur au croisement du droit, de l'éthique et de la politique. Baden-Baden -Zürich/St Gallen: NomosDike.

Fedele, D. (forthcoming). Droit et histoire dans la formation diplomatique d'après les écrits sur l'ambassadeur et l'art de négocier (XVII ${ }^{\mathrm{e}}$-début XVIII ${ }^{\mathrm{e}}$ siècle). Journal of the History of International Law.

Fedele, D. (forthcoming). Grotius and Late Medieval Ius Commune on Rebellion and Civil Strife. Grotiana.

Fiori, R. (1998-1999 [published 2005]). Ius civile, Ius gentium, Ius honorarium: il problema della "recezione" dei iudicia bonae fidei. Bullettino dell'istituto di diritto romano "Vittorio Scialoja” 101-2, pp. 165-97.

Fiori, R. (2016). La nozione di ius gentium nelle fonti di età repubblicana. In: I. Piro (ed.), Scritti per Alessandro Corbino, Volume 3, Tricase: Libellula, pp. 109-29.

Gentilis, A. (1585). De legationibus libri tres. London: excudebat Thomas Vautrollerius.

Gentilis, A. (1924). De legationibus libri tres. Translated by G.J. Laing. Oxford: Oxford University Press.

Gentilis, A. (1598). De iure belli libri III. Hanoviae: excudebat Guilielmus Antonius. 
Gratian (1993). The Treatise on Laws (Decretum DD. 1-20) with the Ordinary Gloss. Translated by A. Thompson O.P. and J. Gordley, with an Introduction by K. Christensen. Washington DC: The Catholic University of America Press.

Grotius, H. (1993). De iure belli ac pacis libri tres. Edited by B.J.A. de Kanter-van Hettinga Tromp, R. Feenstra et al. Aalen: Scientia Verlag.

Grotius, H. (1925). De jure belli ac pacis libri tres, Translated by F.W. Kelsey. OxfordLondon: Clarendon Press-Humphrey Milford.

Haggenmacher, P. (1983). Grotius et la doctrine de la guerre juste. Paris: PUF.

Haggenmacher, P. (2017). Sources in the Scholastic Legacy. Ius Naturae and Ius Gentium Revisited by Theologians. In: S. Besson and J. d'Aspremont, eds., The Oxford Handbook of The Sources of International Law, Oxford et al: Oxford University Press, pp. 45-63.

Henricus de Segusio (1512). Lectura super quinque libris Decretalium. Argentini: impensis Georgij Übelin et Joannes Schottus.

[Hotman, J.] (1603). L'ambassadeur. N.p.: n.p.

[Hotman, J.] (1603). The Ambassador. London: Iames Shawe.

Hotomanus, F. (1573). Quaestionum illustrium liber. N.p.: excudebat Henr. Stephanus.

Iurlaro, F. (2018). Grotius, Dio Chrysostom and the "invention" of Customary ius gentium. Grotiana 39, pp. 1-32.

Kaser, M. (1993). Ius gentium. Köln: Böhlau Verlag.

Keys, M.M. (2017). Religion, Empire, and Law among Nations in The City of God: From the Salamanca School to Augustine, and Back Again. In: M. Koskenniemi et al, eds., International Law and Religion: Historical and Contemporary Perspectives, Oxford: Oxford University Press, pp. 64-86.

Kingsbury, B., Straumann, B., eds. (2010). The Roman Foundations of the Law of Nations: Alberico Gentili and the Justice of Empire. Oxford: Oxford University Press.

Koskenniemi, M. et al, eds. (2017). International Law and Religion: Historical and Contemporary Perspectives. Oxford: Oxford University Press.

Kroger, J.R. (2004). The Philosophical Foundations of Roman Law: Aristotle, the Stoics, and Roman Theories of Natural Law. Wisconsin Law Review 905, pp. 905-44.

Kubben, R. (2011). "We should not stand beside..." International legal doctrine on domestic revolts and foreign intervention throughout the early stages of the Dutch Revolt. In: P. Brood and R. Kubben, eds., The Act of Abjuration. Inspired and Inspirational, Nijmegen: Wolf Legal Publishers, pp. 119-53.

Lesaffer, R., ed. (2004). Peace Treaties and International Law in European History. From the Late Middle Ages to World War One. Cambridge et al: Cambridge University Press. 
Lesaffer, R. (2016). Roman Law and the Intellectual History of International Law. In: A. Orford and F. Hoffmann, eds., The Oxford Handbook of the Theory of International Law, Oxford: Oxford University Press, pp. 38-58.

Lombardi, G. (1947). Sul concetto di “ius gentium”. Milan: Giuffrè.

Longfield Karr, S. (2016). Redefining Ius to Restore Justice: the Centrality of Ius Gentium in Humanist Jurisprudence. In: P.J. du Plessis and J.W. Cairns, eds., Reassessing Legal Humanism and its Claims. Petere Fontes?, Edinburgh: Edinburgh University Press, pp. 10834.

McManus, B. (1999). The Consilia and Quaestiones of Oldradus de Ponte. Bulletin of Medieval Canon Law 23, pp. 85-113.

Montagu, G. (1994). Roman Law and the Emperor: The Rationale of "Written Reason" in Some Consilia of Oldradus da Ponte. History of Political Thought 15, pp. 1-56.

Oldradus de Ponte (1585). Consilia seu responsa et quaestiones aureae. Venetiis: ex Officina Damiani Zenari.

Padovani, A., and Stein, P.G., eds. (2007). The Jurists' Philosophy of Law from Rome to the Seventeenth Century. Dordrecht et al: Springer.

Padovani, A. (2011). "Tenebo hunc ordinem". Metodo e struttura della lezione nei giuristi medievali (secoli XII-XIV). Tijdschrift voor Rechtsgeschiedenis 79, pp. 353-89.

Paulus Castrensis (1585). In Primam Digesti Vateris partem Commentaria. Lugduni: excudit Ant. Blanc.

Puliatti, S. (2012). Ius gentium e disciplina dei rapporti internazionali in Isidoro di Siviglia. In: G. Bassanelli Sommariva and S. Tarozzi, eds., Ravenna Capitale. Uno sguardo ad Occidente. Romani e Goti - Isidoro di Siviglia, Santarcangelo di Romagna: Maggioli, pp. 27-38.

Sasaki, Y. (1985). Ius gentium in der Lehre des Bartolus. In: J.A. Ankum et al, eds., Satura Roberto Feenstra sexagesimum quintum annum aetatis complenti ab alumnis collegis amicis oblata, Fribourg: Éditions universitaires de Fribourg, pp. 421-36.

Scattola, M. (1999). Das Naturrecht vor dem Naturrecht: zur Geschichte des "ius naturae" im 16. Jahrhundert. Tübingen: Max Niemeyer.

Schiavone, A. (2012). The Invention of Law in the West. Translated by J. Carden and A. Shugaar. Cambridge et al.: Harvard University Press.

Scott, S.P. (1932). The Civil Law. Cincinnati: The Central Trust Company, available at https://droitromain.univ-grenoble-alpes.fr.

Setserus, H. (1600). Legatus: sive de Legatis Principum \& Rerumpublicarum Discursus politicus, respondente J-.E. a Worm. Frankfurt an der Oder: typis A. Eichorns.

Steiger, H. (2009 [or. ed. 1993]). Völkerrecht. In: Id., Von der Staatengesellschaft zur Weltrepublik? Aufsätze zur Geschichte des Völkerrechts aus vierzig Jahren. Baden-Baden: Nomos, pp. 15-65.

Stein, P.G. (1999). Roman Law in European History. Cambridge: Cambridge University Press. 
Stein, P.G. (2007). The Roman Jurists' Conception of Law. In: A. Padovani and P.G. Stein, eds., The Jurists' Philosophy of Law from Rome to the Seventeenth Century, Dordrecht: Springer, pp. 1-30.

Stickler, A.M. (1959). Alanus Anglicus als Verteidiger des monarchischen Papsttums. Salesianum 21, pp. 346-406.

Suarez, F. (1612). Tractatus de legibus ac Deo legislatore. Coimbra: Apud Didacum Gomez de Loureyro.

Thier, A. (2015). Historische Semantiken von ius gentium und "Völkerrecht". In: T. Altwicker, ed., Völkerrechtsphilosophie der Frühaufklärung, Tübingen: Mohr Siebeck, pp. 29-47.

Thomas Aquinas (1947-1948). Summa theologica. Translated by the Fathers of the English Dominican Province. New York: Benziger Brothers.

Tierney, B. (1988). The Crisis of Church and State: 1050-1300. Toronto: University of Toronto Press.

Todescan, F. (2014). Jus gentium medium est intra jus naturale et jus civile: la "double face" du Droit des Gens dans la scolastique espagnole du $16^{\text {ème }}$ siècle. In: P.-M. Dupuy and V. Chetail, eds., The Roots of International Law. Les fondements du droit international. Liber Amicorum Peter Haggenmacher. Leiden-Boston: Martinus Nijhoff, pp. 121-80.

Turelli, G. (2011). 'Audi Iuppiter'. Il collegio dei feziali nell'esperienza giuridica romana. Milan: Giuffrè.

Valenzuela, P. (2017). Between Scylla and Charybdis. Aquinas's Political Thought and His Notion of Natural Law and Ius Gentium. In: M. Koskenniemi et al, eds., International Law and Religion: Historical and Contemporary Perspectives, Oxford: Oxford University Press, pp. 4363.

Vattel, E. de (1758). Le droit des gens. London [recte Neuchâtel]: [Abraham Droz].

Vattel, E. de (1916). Le droit des gens. Translated by Charles G. Fenwick. Washington DC: Carnegie Institution of Washington.

Vauthier Borges de Macedo, P.E. (2017). Catholic and Reformed Traditions in International Law. A Comparison between the Suarezian and the Grotian Concepts of Ius Gentium. Cham: Springer.

Vitoria, F. de (1917). De Indis et de Iure Belli Relectiones. Edited by Herbert F. Wright. Washington DC: Carnegie Institution of Washington.

Vitoria, F. de (1934). Comentarios a la Secunda secundae de Santo Tomás, Volume 3. Edited by V. Beltran de Heredía. Salamanca: Dominicos de la Provincias de Espana.

Vitoria, F. de (1991). Political writings. Edited by A. Pagden and J. Lawrance. Cambridge et al: Cambridge University Press.

Vitoria, F. de (2008). Relectio de Potestate Civili. Estudios sobre su Filosofia Política. Edited by J. Cordero Pando. Madrid: Consejo Superior de Investigaciones Científicas. 
Voigt, M. (1875). Die Lehre vom ius naturale, aequum et bonum und ius gentium der Römer. Leipzig: Enrst Julius Günther 1875 [reprint 1966 Aalen: Scientia Verlag 1966].

Waelkens, L. (1992). La Lectura Institutionum de Raoul d'Harcourt. Rivista internazionale di diritto comune 3, pp. 79-91.

Watson, A., ed. (1985). The Digest of Justinian. (4 vols). Philadelphia: University of Pennsylvania Press.

Watson, A. (1993). International Law in Archaic Rome: War and Religion. Baltimore-London: Johns Hopkins University Press.

Weigand, R. (1967). Die Naturrechtslehre der Legisten und Dekretisten von Irnerius bis Accursius und von Gratian bis Johannes Teutonicus. München: Max Hueber Verlag.

Wijffels, A. (1994). Ius gentium in the practice of the Court of Admiralty around 1600. In: A.D.E. Lewis and D.J. Ibbetson, eds., The Roman Law Tradition. Cambridge: Cambridge University Press, pp. 119-34.

Wijffels, A. (2011). Early-modern scholarship on international law. In: A. Orakhelashvili, ed., Research Handbook on the Theory and History of International Law, CheltenhamNorthampton MA: Edward Elgar, pp. 23-60.

Winkel, L. (1988). Die stoische oikeiosis-Lehre und Ulpians definition der gerechtigkeit. Zeitschrift der Savigny-Stiftung für Rechtsgeschichte. Romanistische Abteilung 105, pp. 66979.

Winkel, L. (1993). Einege Bemerkungen über ius naturale und ius gentium. In: M.J. Schermaier and Z. Végh, eds., Ars boni et aequi. Festschrift für Wolfgang Waldstein zum 65. Geburstag, Stuttgart: Franz Steiner, pp. 443-9.

Winkel, L. (2004). The Peace Treaties of Westphalia as an instance of the reception of Roman law. In R. Lesaffer (ed.), Peace Treaties and International Law in European History. From the Late Middle Ages to World War One, Cambridge et al: Cambridge University Press, pp. 22237.

Winkel, L. (2013). Ius gentium. In: R.S. Bagnall et al, eds., The Encyclopedia of Ancient History, Malden: Wiley-Blackwell, pp. 3553-4.

Ziegler, K.-H. (1995). Ius gentium als Völkerrecht in der Spätantike. In: R. Feenstra et al, eds., Collatio iuris Romani. Études dédiées à Hans Ankum à l'occasion de son $65^{e}$ anniversaire, Volume 2, Amsterdam: J.C. Gieben, pp. 665-75.

Z[ouche], R. (1650). Iuris et iudicii fecialis, sive iuris inter gentes, et quaestionum de eorum explicatio. Oxoniae: excudebat H. Hall, impensis Tho. Robinson. 